IZA DP No. 6210

Height and Cognitive Function among Older Europeans: Do People from "Tall" Countries Have Superior Cognitive Abilities?

Cahit Guven

Wang-Sheng Lee

December 2011 


\title{
Height and Cognitive Function among Older Europeans: Do People from "Tall" Countries Have Superior Cognitive Abilities?
}

\author{
Cahit Guven \\ Deakin University \\ Wang-Sheng Lee \\ RMIT University \\ and IZA \\ Discussion Paper No. 6210 \\ December 2011 \\ IZA \\ P.O. Box 7240 \\ 53072 Bonn \\ Germany \\ Phone: +49-228-3894-0 \\ Fax: +49-228-3894-180 \\ E-mail: iza@iza.org
}

\begin{abstract}
Any opinions expressed here are those of the author(s) and not those of IZA. Research published in this series may include views on policy, but the institute itself takes no institutional policy positions.

The Institute for the Study of Labor (IZA) in Bonn is a local and virtual international research center and a place of communication between science, politics and business. IZA is an independent nonprofit organization supported by Deutsche Post Foundation. The center is associated with the University of Bonn and offers a stimulating research environment through its international network, workshops and conferences, data service, project support, research visits and doctoral program. IZA engages in (i) original and internationally competitive research in all fields of labor economics, (ii) development of policy concepts, and (iii) dissemination of research results and concepts to the interested public.
\end{abstract}

IZA Discussion Papers often represent preliminary work and are circulated to encourage discussion. Citation of such a paper should account for its provisional character. A revised version may be available directly from the author. 


\begin{abstract}
Height and Cognitive Function among Older Europeans: Do People from "Tall" Countries Have Superior Cognitive Abilities?"

Previous research has found that height is correlated with cognitive functioning at older ages. It therefore makes sense to ask a related question: do people from countries where the average person is relatively tall have superior cognitive abilities on average? Using data from the Survey of Health, Ageing, and Retirement in Europe (SHARE), we find empirical evidence that this is the case, even after controlling for self-reported childhood health, selfreported childhood abilities, parental characteristics and education. We find that people from countries with relatively tall people, such as Denmark and the Netherlands, have on average superior cognitive abilities compared to people from countries with relatively shorter people, such as Italy and Spain. We exploit variations in height trends due to nutritional deprivation in World War II in Europe and use an instrumental variable analysis to further estimate the potential impact of height on cognitive function. We find some suggestive evidence that a causal link from height to cognitive outcomes could be operating via nutrition and not via educational attainment.
\end{abstract}

JEL Classification: C21, J24, N3

Keywords: height, cognitive function, instrumental variables, World War II

Corresponding author:

Wang-Sheng Lee

RMIT University

Level 12

School of Economics, Finance and Marketing

239 Bourke Street

Victoria 3000

Australia

E-mail: wangsheng.lee@rmit.edu.au

\footnotetext{
${ }^{*}$ We are grateful to Sandra Black, Colin Cameron, Daniel Hamermesh, David Johnston, Robin Sickles and Bent Sorensen for valuable comments and suggestions, as well as seminar participants at the University of Texas at Austin and Monash University, and participants at the 2011 Labor Econometrics Workshop in Sydney.
} 


\section{Introduction}

Previous research on the influence of early-life conditions on cognitive development suggests that socioeconomic conditions in childhood and early life experiences have important influences on cognitive development and abilities in childhood and adolescence, as well as in young and middle adulthood. For example, children from poor backgrounds show worse verbal and achievement outcomes in the first 5 years of life (Duncan et al., 1994). Low socioeconomic status in childhood has also been associated with cognitive function in middle age, net of years of education completed (Kaplan et al., 2001). It is only in recent years that researchers adopting a life course approach have begun to trace the origin of cognitive functioning in old age to early life conditions. For example, using longitudinal data in conjunction with retrospectively collected childhood data, Everson-Rose et al. (2003) and Zhang et al. (2008) all find that higher socioeconomic status during childhood are weakly associated with a higher absolute level of cognitive function in old age. More recently, Van den Berg et al. (2010) use a unique Dutch longitudinal dataset to examine the role of early life socio-economic circumstances in protecting individuals from cognitive decline in the face of adverse events later in life. They show that the cognitive abilities of those who suffer from strokes later in life are more heavily affected if individuals were born in adverse socioeconomic conditions.

In the absence of reliable data from early childhood, several recent studies use adult height as a marker of childhood circumstances. ${ }^{1}$ For example, Case and Paxson (2008a) suggest that height could be an indicator of higher cognitive potential in the sense that people who do not reach their full genetic height potential do not reach their full genetic cognitive potential either. They provide evidence that taller individuals are more likely to earn more, not because of their heights per se, but because of the cognitive skills with which height is correlated. Using data from the U.S. Health and Retirement Study (HRS), Case and Paxson (2008b) document a strong association between self-reported height and cognitive function in later life. Similarly, Maurer (2010) complements the evidence presented in Case and Paxson (2008b) by examining the later-life cognition of seniors in Latin America and the Caribbean using data from the Survey on Health, Well-being and Aging in Latin America and the Caribbean, 2000 (SABE). He finds that that height displays a strong positive association with later life cognition, which seems somewhat larger for women than for men. Using data from

\footnotetext{
${ }^{1}$ There is a large literature in economic history that uses height as a key measure of physical welfare and the standard of living. See, for example, the surveys by Steckel $(1995,2009)$. Aside from genetics, it has been established that height is influenced by childhood nutrition and disease (e.g., Fogel, 1993; Peck and Lundberg, 1995). Hence, height is commonly seen as a useful marker of overall childhood conditions.
} 
the English Longitudinal Survey of Aging (ELSA), Guven and Lee (2011) also find the same association for English men and women. This positive association appears to start from a young age - Schick and Steckel (2010) find using the National Childhood Development Study (NCDS) that taller children have higher average cognitive test scores. On the other hand, Heineck (2009) uses the German Socio-Economic Panel for his analysis and finds that in a sample of adults aged 16 years or older, height is only associated with males' cognitive abilities but not in the case for females. In general, these studies build on the earlier work of psychologists who have previously noted that height appears to be positively correlated with intelligence (e.g., Jensen and Sinha, 1993; Johnson, 1991).

If within country studies such as those mentioned above find a significant association between height and cognitive function, it is natural to also ask whether such a correlation exists for individuals across countries. Do people from countries where the average native person is relatively tall have superior cognitive abilities compared to people from countries where the average native person is relatively short? It is well known that the average heights differ across nationalities considerably. Do the taller Austrians and Danes, for example, have higher cognitive abilities than the shorter Italians and Spaniards?

In this paper, using data from the Survey of Health, Ageing, and Retirement in Europe (SHARE), we examine the relationship between height and cognitive function in a sample of older Europeans. Our contributions are threefold. First, we add to the current literature by extending the work of Case and Paxson (2008b), Maurer (2010) and Guven and Lee (2011) by examining the relationship between height and later life cognition in 13 additional European countries not previously analyzed. Second, we extend the within-country analysis to a cross-country analysis to determine if countries with relatively tall people have higher levels of cognitive function than countries with relatively short people. Third, we exploit an exogenous nutritional shock due to World War II and conduct an instrumental variable analysis in an attempt to make a causal link between height and cognitive outcomes. This idea for an instrument is similar to an application in Ichino and Winter-Ebmer (2004), who use World War II as an instrument for years of education for cohorts born in the 1930s. A key difference in our application is that we focus on a younger cohort and use the war as an instrument for height.

The rest of the paper is organized as follows. Section 2 provides a survey of work that has been done on explaining cross-country differences in cognitive ability and discusses what possible links there might be between height and cognitive ability. Section 3 describes the data we use for our analysis. Section 4 presents the empirical results for each European 
country. Section 5 presents the cross-country results. In section 6, we present results from the instrumental variable analysis. Finally, section 7 concludes.

\section{Background}

\subsection{Cross-Country Variation in Height}

Garcia and Quintana-Domeque (2007) document the evolution of adult heights in Europe in the period 1950-1980. They find that average height in the Northern European countries (Austria, Belgium, Denmark, Finland, Ireland, and Sweden) is higher than in the Southern ones (Greece, Italy, Portugal, and Spain) for both males and females. Hatton and Bray (2010) extend the database constructed by Garcia and Quintana-Domeque (2007) by going through a variety of historical records to include the average heights of men by birth cohorts from 1856-60 to 1976-80. Eveleth and Tanner (1990) produced a world-wide overview of variations in growth among children aged 2 to 16 years. They used data from studies undertaken from the 1950 s to the 1980s that were based on nationally representative samples or on samples from large cities within the countries studied. Identical growth curves were observed for European countries. However, at age 16, they also found that children in northern European countries were on average taller than children in southern European countries. Similarly, when De Groot et al. (1991) compared the height of elderly subjects born between 1913 and 1918 in 19 cities across Europe, they found that these subjects were tallest in northern European populations. ${ }^{2}$ In this paper, we exploit this variation in height across European countries and explore in more detail whether adult height is useful as a marker of cognitive ability.

\subsection{Possible Explanations for Cross-Country Variation in Cognitive Ability}

Technological progress of nations, a key ingredient of a country's economic success and the wealth and well-being of its citizens, has been shown to be related to average national levels of intelligence (e.g., Gelade, 2008). It is therefore of great interest how cross-country differences in cognitive abilities arise. Several hypotheses have been put forth in attempts to explain the variation in the global distribution of cognitive ability. These include exposure to education and other cognitively challenging environments such as non-agricultural labor,

\footnotetext{
${ }^{2}$ Although there is a large genetic component to heights within populations, the contribution of genetics to variation in mean heights across populations is much smaller. For example, Beard and Blaser (2002) argue that the marked increase in heights observed throughout the developed world during the twentieth century occurred too rapidly to be due to selection and genetic variation. Silventoinen (2003) provides a summary of factors thought to affect adult body height, emphasizing the need for more work to be done on the interaction between genetic and environmental factors.
} 
differing levels on inbreeding across countries, the effects of temperature and climate, as well as the effects of variation in the intensity of infectious diseases.

Using data on intelligence quotient (IQ) scores for 81 nations and focusing on bivariate correlations, Barber (2005) finds that average national IQ to be correlated with enrolment in secondary school $(r=0.72)$, illiteracy $(r=-0.71)$, agricultural labour $(r=-0.70)$ and gross national product $(\mathrm{r}=0.54)$. He also proposed that health and nutrition may affect intelligence, and found that average national IQ correlated negatively with rates of low birth weight $(r=-0.48)$ and with infant mortality $(r=-0.34)$.

Saadat (2008) and Woodley (2009) explore the hypothesis that inbreeding and the associated reduced phenotypic quality is a cause of the variation in cognitive ability across the world. Consanguineous marriages (i.e., a marriage between first or second cousins) account for a significant percentage of marriages in some countries. Although stigmatized in the West, such marriages are common in many Middle Eastern countries such as Saudi Arabia (39.7\%) and Qatar (44.5\%), as well as African countries such as Sudan (50.1\%) and Nigeria $(51.2 \%){ }^{3}$ In support of this hypothesis, Saadat (2008) and Woodley (2009) found significant cross-national correlations in the range of -0.6 to -0.8 between average IQ and measures of inbreeding. In related work, Jensen (1983) finds that the effect of inbreeding on the intelligence of the offspring of first cousins amounts to about 5 IQ points.

Lynn (1991) and Rushton (1995) proposed that temperature and climate provide important Darwinian selective pressures for intelligence, with cold climates selecting for higher intelligence, because low temperatures provide more fitness-related problems for humans that must be solved through cognitively demanding means, and through more complex social organization. Some empirical support for this hypothesis was reported in Templer and Arikawa (2006) who found that persons in colder climates tend to have higher IQ scores.

Finally, Eppig et al. (2010) have recently provided empirical evidence using a sample of over 100 countries that average national intelligence correlates significantly and negatively with rates of infectious disease. This is possible because parasitic infection may intermittently cause the redirection of energy away from brain development during the crucial years of childhood development.

\footnotetext{
${ }^{3}$ These figures are taken from Appendix A in Woodley (2009).
} 


\subsection{Do Cross-Country Differences in Height have any Economic Significance?}

In this paper, we explore yet another hypothesis to explain cross-country variation in cognitive abilities - the role of height. Somewhat related to this hypothesis are papers by Angus Deaton and his co-authors exploring the significance of cross-country differences in height. Deaton (2007) analyses the link between adult height, disease and national income using data on 43 countries from the Demographic and Health Surveys. With the exception of Africa, he finds there is a general interregional correspondence between height and national income. Over time, as real incomes have grown, heights have grown too.

In a related paper, Bozzoli, Deaton and Quintana-Domeque (2009) focus their analysis on adult height and childhood disease in the US, England and ten European countries where more detailed household level data are available. They find that both within and between these countries, there is a close relationship between income per capita and height. Their findings also suggest that the direction of causality does not appear to run from income to height, as they find that the disease environment in infancy is the most important determinant of adult height, not the level of income per head. Indirectly, the role of height is also possibly related to the Eppig et al. (2010) hypothesis involving the role of infectious diseases in influencing cognitive functioning, as children who get sick when they are very young might suffer some physical developmental consequences. ${ }^{4}$

\subsection{Possible Links between Height and Cognitive Ability}

To date, the precise mechanisms underlying the relationship between height and IQ are still not well understood. Case and Paxson's (2008b) study highlights the crucial role of education as a potential pathway linking height and cognitive function in later life. They find that there is a statistically significant positive association between cognitive function and selfreported height, which declines considerably once they control for education. They also highlight a positive association between education and height. Taken together, these findings suggest that early-life conditions have an effect on later-life cognition results partly due to higher levels of schooling among children with higher socioeconomic status, which may, in turn, protect cognitive function at older ages.

Other mechanisms that produce a positive correlation between height and intelligence have been suggested. It is possible that an unmeasured factor simultaneously affects cognitive

\footnotetext{
${ }^{4}$ They could, however, be very distinct hypotheses. As we report in Section 4, to the extent that self-reported information on childhood diseases is reliable, we find that childhood diseases have little effects on reducing the statistical significance of height in our cognitive function regressions we estimate (see discussion of Table 4).
} 
ability and height. For example, Lynn (1990) emphasizes the role of nutrition, arguing that the most straightforward explanation of the positive association between height and intelligence is that both are functions of nutrition. He argues that improvements in nutrition have led to parallel increases in height, head circumference, brain size, and to improved neurological development and functioning of the brain. The role played by nutrition in linking height and cognitive functioning has been supported by twin studies. Black et al. (2007a) find that, on average, the twin born at the higher birth weight is significantly taller in adulthood and scores significantly higher on IQ tests. Similarly, using data from the Minnesota Twin Registry, Behrman and Rosenzweig (2004) find fetal growth (birth weight divided by gestation) to be significantly associated with height and years of completed schooling in adulthood.

On the other hand, biological factors could be important - people with greater genetic quality and developmental health may simultaneously have higher intelligence and greater stature. However, understanding the precise mechanisms by which height and intelligence are related is not an easy task due to the fact that both height and intelligence are polygenic traits. ${ }^{5}$ Twin studies have been used to decompose the components of the height-intelligence correlation due to early childhood environmental factors (such as prenatal and postnatal nutrition or cognitive stimulation) and shared genes. Sundet et al. (2005), using conscription data of Norwegian twins, conclude that the environment plays a large role and is responsible for 65 percent of the height-intelligence correlation, with genes responsible for 35 percent of the observed correlation. Beauchamp et al. (2010), using a sample of Swedish twins, find results that are very similar to those reported by Sundet et al. (2005). However, these findings are not conclusive. Silventoinen et al. (2006) found in several samples of Dutch twins that the association between height and intelligence is primarily genetic in origin.

Kanazawa and Reyniers (2009) propose a somewhat more lengthy explanation comprising of three separate mechanisms and involving genetic evolution over time. The first mechanism involves the assortative mating of tall men and beautiful women. As height is desirable in men and physical attractiveness is desirable in women, there should be assortative mating between tall men and beautiful women (and short men and less beautiful women). Since both height and physical attractiveness are heritable, this will create a correlation among their children between height and physical attractiveness, where tall people

\footnotetext{
${ }^{5}$ Explaining traits which are polygenic in nature is very challenging. Although genome-wide association studies have detected 40 areas of the DNA that affect height, to date, variations in these regions of the genome can explain less than 10 percent of the heritability of height in humans (Allen et al., 2010).
} 
(both men and women) are more beautiful than short people. The second mechanism involves the assortative mating of intelligent men and beautiful women. As intelligent men tend to attain higher status (which is a desirable trait in men from a women's perspective) and because physical attractiveness is desirable in women, there should be assortative mating between intelligent (and thus high-status) men and beautiful women. Since both intelligence and physical attractiveness are heritable, this will create a correlation among their children between intelligence and physical attractiveness, where more attractive people are more intelligent than less attractive people. Finally, the correlation between height and physical attractiveness (produced by the first mechanism above) and correlation between intelligence and physical attractiveness (produced by the second mechanism above) will create a secondorder correlation between height and intelligence.

Assumptions made on the degree of assortative mating that occurs can have an effect on the importance one attributes to genetic factors. In their decomposition of the components of the height-intelligence correlation due to environmental and genetic factors, Beauchamp et al. (2010) find that by varying the levels of assortative mating slightly, the estimated share of the height-intelligence correlation attributed to genetic factors can be increased significantly.

There is also a possible link between birth order, height and cognitive functioning. Evidence for a significant effect of birth order on IQ, where earlier born children have higher IQs, include the studies by Belmont and Marolla (1973) and Black et al. (2007b), although such findings are still somewhat contentious (e.g., see Rodgers et al., 2000). There is also evidence in the literature supporting the notion that later born children are shorter (e.g., Li and Power, 2004), suggesting that it is plausible that birth order affects both height and cognitive functioning, where earlier born children are taller and more intelligent.

\section{Data}

In this study, we use data on cognitive functioning from Waves 1 and 2 of SHARE (Release 2.5.0 of May 24, 2011). The first wave was fielded in 12 countries in 2004/2005: Austria, Belgium, Denmark, France, Greece, Germany, Italy, the Netherlands, Sweden, Switzerland, Spain and - one year later - Israel. In all countries, probability samples of nationally representative samples of the community-based population aged 50 and older were drawn. The 31,000 interviews conducted in that period correspond to a weighted average household response rate of 61 percent, ranging from 39 percent in Belgium and Switzerland to 79 percent in France (a thorough description of methodological issues is contained in Börsch-Supan and Jürges, 2005). The second wave in 2006/2007 opened the longitudinal 
dimension, but also collected baseline data from three further countries: the Czech Republic, Poland and - after some delay - Ireland.

We also use data from the third wave of data collection for SHARE. This data, which was in the field from October 2008 to May 2009, focuses on people's life histories and is otherwise commonly referred to as SHARELIFE. Waves 1 and 2 of SHARE provide little information about what happened earlier in the lives of survey respondents. SHARELIFE gathered more detailed information on important areas of our respondents' lives, ranging from partners and children over housing and work history to detailed questions on health and health care. It therefore complements the SHARE panel data by providing life history information and enhancing our ability to understand how early life experiences and events throughout life influenced the circumstances of the survey respondents. SHARELIFE data are available for all the countries in SHARE with the exception of Ireland and Israel, which is the reason we do not include them in our analysis.

SHARE is designed to be cross-nationally comparable and is harmonized with the U.S. Health and Retirement Study (HRS) and the English Longitudinal Study of Ageing (ELSA). International comparability is achieved by ex-ante harmonization of the survey instrument and all fieldwork procedures. The common questionnaire and interview mode, the effort devoted to translation of the questionnaire into the national languages of each country, and the standardization of fieldwork procedures and interviewing protocols are the most important design tools adopted to ensure cross-country comparability (Börsch-Supan and Jürges, 2005).

In SHARE, cognitive ability is measured using simple tests of orientation in time, memory (registration and recall of a list of ten words), verbal fluency (a test of executive function) and numeracy (arithmetical calculations). Participants are also asked to rate subjectively their reading and writing skills. These tests are administered to all respondents and are carried out after the first four modules (Cover Screen, Demographics and Networks, Physical Health, and Behavioral Risks) of the questionnaire. The tests are comparable with similar tests implemented in the HRS and ELSA, and follow a protocol aimed at minimizing the potential influences of the interviewer and the interview process. ${ }^{6}$

The test of orientation in time consists of four questions about the interview date (day, month, year) and day of the week. Unfortunately, this test shows very little variability across

\footnotetext{
${ }^{6}$ An important drawback of SHARE is that the exact same tests were administered to all respondents of the same household and to the same individual over time. Repeated exposure to the same tests may induce learning effects which are likely to improve the cognitive scores of some respondents.
} 
respondents, with a majority of respondents answering all four questions correctly. Nevertheless, we include it in this paper for comparability purposes with Case and Paxson (2008b).

The test of memory consists of a verbal recall of a list of 10 words (butter, arm, letter, queen, ticket, grass, corner, stone, book and stick). The respondent hears the complete list only once and the test is carried out two times, immediately after the words are read out (immediate recall) and at the end of the cognitive function module (delayed recall). The raw total scores of both tests correspond to the number of words that the respondent recalls.

The test of verbal fluency consists of counting how many distinct elements from a particular category the respondent can name in a specific time interval. The specific category used in SHARE is members of the animal kingdom (real or mythical, except repetitions or proper nouns) and the time interval is one minute for all respondents.

The test of numeracy consists of a few questions involving simple arithmetical calculations based on real life situations. Respondents who correctly answer the first question are asked a more difficult one, while those who make a mistake are asked an easier one. The last question is about compound interest, testing basic financial literacy. The resulting raw total score ranges from 0 to 4 . Finally, respondents are also asked to rate their reading and writing skills on a five point scale, which we have recoded as: Excellent $=5$, Very good $=4$, Good $=3$, Fair $=2$, Poor $=1$.

Our height measure in SHARE is based on self-reported height ("How tall are you?"). One potential issue with taking height measurements over time of older people is that there could be shrinkage as a result of bone density loss. We use the earliest reported height measurements of an individual in each case for the purposes of our analysis (i.e., from wave 1) to avoid any potential issues with shrinkage. Although many studies have observed a very high correlation between measured height and self-reported height, these studies also found that using self-reported height leads to a slight overestimation of the average height of the study population (e.g., Palta et al., 1982; Steward, 1982). Moreover, these studies showed that this overestimation was larger among men, among older age groups, and among lower socio-economic groups. However, where the focus is on cross-national comparisons the main results will only be biased when this over- or underestimation also varies between countries. Supporting the use of our data is that the large variations in average height we observed between northern and southern European countries were also reported in studies in which height was measured (Eveleth and Tanner, 1990; de Groot et al., 1991). Further reducing the need for a concern that the use of self-reported height in SHARE leads to bias is that when 
we regressed measures of cognitive function on two available height measures in ELSA (both self-reported height and nurse measured height), we found very similar results.

Given our interest in analysing height differences across nationalities, we restrict our sample to respondents who were born in the countries they are currently residing in and omit observations from any immigrants.

\section{Results for Individual European Countries}

In this section, we focus on replicating the country studies of Case and Paxson (2008b), Maurer (2010) and Guven and Lee (2011) who report significant associations between height and cognitive function in later life. It is interesting to see if their results hold for many of the developed European countries. We focus on analyzing data from 13 European countries - Ireland and Israel are excluded because they do not have childhood history data from SHARELIFE. Table 1 provides descriptive statistics of height, the seven cognitive function variables we use in our analysis, as well as key control variables.

[Table 1 about here]

Using pooled data, the estimated results in which these seven cognitive measures are regressed on respondents' heights (measured in centimetres), age, gender, country dummies and survey wave are reported in Table 2. Focusing on the coefficient for height, for all 13 European countries as a whole, it can be seen that it is highly statistically significant in columns one to seven, suggesting that taller persons perform better on average in the cognitive tests as compared to their shorter counterparts.

[Table 2 about here]

Table 3 presents the results of regressions similar to those in Table 2, with the difference that following Case and Paxson (2008b) extra control variables for education, father's occupation at age 10 and self-reported childhood health have been added. Strikingly, despite the inclusion of education as a control variable, a factor which largely diminished the role of height in similar regressions estimated in Case and Paxson (2008b), the height coefficient is still statistically significantly correlated with our seven measures of cognitive 
functioning. ${ }^{7}$ This suggests that in the SHARE data, height does not only operate via education in affecting cognitive outcomes. ${ }^{8}$

\section{[Table 3 about here]}

In Table 4, we add childhood history variables to the regressions on cognitive functioning estimated in Table 3. These include childhood environmental measures such as parental drinking and smoking behavior at age 10, presence of both parents in the household at age 10, number of people in the household at age 10 (to reflect competition for household resources) and number of rooms in the household at age 10 (as a proxy for household wealth). In addition to childhood history variables, we include several other variables in the regressions that others have identified as being potentially important in affecting childhood development and indirectly affecting adult height and cognitive functioning. As discussed in a previous section, as birth order could possibly affect both height and cognitive functioning, where earlier born children are taller and more intelligent, we also include this variable in the regression models on cognitive outcomes. Finally, as handedness might also be related to cognitive functioning (e.g., Johnston et al., 2009), we also include information on whether the respondent is left- or right-handed in our model.

Interestingly, comparing the coefficients for height in Tables 3 and 4, we can see that the inclusion of more detailed childhood history variables and other relevant variables we hypothesize to be associated with cognitive functioning in later life hardly has any effects on the size of the height coefficient for all seven cognitive outcomes. The results in Table 4 suggest that a $10 \mathrm{~cm}$ (or 3.94 inches) increase in height is associated with an increase of 0.08 points in reading skill (measured on a scale of 1-5), an increase of 0.07 points in writing skill (measured on a scale of 1-5), an increase of 0.41 points in verbal fluency (measured on a scale of 0-100), an increase of 0.08 points in immediate recall (measured on a scale of $0-10$ ), an increase of 0.10 points in delayed recall (measured on a scale of $0-10$ ), and an increase of 0.02 points in numeracy (measured on a scale of $0-1$ ). These generally translate to $2-3$ percent increases based on the means of the outcome variables reported in Table 1. The

\footnotetext{
${ }^{7}$ Consistent with our findings, Case and Paxson (2010) report finding that the association between height and cognitive outcomes is only partially mediated by schooling using data from the British National Child Development Study (NCDS), the British Cohort Study (BCS), the British Whitehall II Study data, and data from the US Panel Study of Income Dynamics (PSID). Guven and Lee (2011) also find a similar result using the ELSA data.

${ }^{8}$ As in Case and Paxson (2008b), however, we do find that height is significantly and positively associated with years of schooling and occupational choice. See Table A.1 in the appendix.
} 
corresponding results in terms of standardized coefficients are reported in Table A.2 in the appendix. ${ }^{9}$ Among the other covariates of interest, we find that first born children are $0.4 \mathrm{~cm}$ taller than last born ones, and that first born children score higher on all cognitive functioning measures than children born later. We also find that left-handed people are $0.2 \mathrm{~cm}$ shorter than right-handed people and that they score lower on all cognitive functioning measures than right-handed people.

[Table 4 about here]

The adverse early-life conditions that affect cognitive functioning that have been studied are mostly nutritional (e.g., Lynn, 1989; Kretchmer et al., 1996). However, exposure to high levels of stress or illness during the critical childhood years - a much less researched area - could also have important effects. In an attempt to test whether childhood health shocks might have affected both height and cognitive development, we also tried including detailed information regarding childhood health conditions in SHARE. This information on childhood health histories was collected retrospectively in SHARELIFE. Although scepticism regarding the respondents' ability to remember events taking 50 years ago or longer is understandable, as Smith (2009) discusses, respondents appear to remember important childhood events about themselves, such as illnesses they had during childhood, quite well. The childhood illnesses we have information on include: whether or not missed school due to health problems, infectious diseases, broken bones/fractures, asthma, other allergies, other respiratory problems, chronic ear problems, severe headaches and migraines, epilepsy/seizures/fits, emotional/psychological problems, appendicitis, diabetes/high blood sugar, heart trouble, leukaemia/lymphoma, cancer/malignant tumor, diseases of the blood, diseases of digestive system, and upper respiratory organs diseases. Despite restricting the first occurrences of these health conditions to ages 0 to 5 , we found that these variables did not reduce the statistical significance for height (results not shown). ${ }^{10}$

We next turn to examining the country specific results not reported in Tables 2 to 4 , which is essentially a replication of the analysis using the HRS by Case and Paxson (2008b) for each of the 13 European countries in the SHARE data set. Based on separate regressions

\footnotetext{
${ }^{9}$ In Table A.2 in the appendix, we also estimate the regression in Table 4 on a variety of subsamples and find that the association between height and cognitive outcomes is robust across subgroups.

${ }^{10} \mathrm{We}$ also experimented with the use of a relative height measure (i.e., the difference between the respondent's height and the mean male/female height in his/her country of residence) in different forms in the regressions, the idea being that how one is perceived in one's country might matter for our outcomes of interest. However, with height also included in the model, relative height was never statistically significant in our regression models.
} 
estimated for each country, we can see that the coefficient on height in the regressions for each country is statistically significant in the majority of cases (Table 5). The height coefficient is generally not significant for the test on orientation in time (column 3) because of little variation in the test score, with most people scoring close to full marks in the test (mean of 3.81 out of 4 ).

\section{[Table 5 about here]}

Our results for 13 additional European countries provide more empirical support for the link between height and cognitive functioning. However, it is less clear what channels height operates through to affect cognitive functioning in later ages. Our evidence suggests that education is not the main pathway that height affects cognitive functioning, as including years of schooling did not affect the significance of the height coefficient. We also tried including information on the highest degree earned, but this made no substantive difference. It is likely that height captures some other aspects of early childhood health experiences that we are unable to measure, or alternatively some other factors associated with cognitive functioning that we have not included in our models. ${ }^{11}$

\section{Cross-Country Differences in Cognitive Function}

In this section, we extend the within-country analysis conducted thus far to a crosscountry framework. If tall people within each country demonstrate superior cognitive abilities relative to shorter people, and this finding appears to be very robust for many different countries, then it is natural to wonder if people from countries with relatively tall people have superior cognitive abilities as compared to people from countries with relatively short people.

\subsection{Cross-Country Results using SHARE}

Figure 1 provides average height by country for the both men and women, as well as separately by gender. It can be seen that the Dutch are the tallest in the sample, with male average heights of about 1.78 metres and female average heights of about 1.66 metres. The Danes and the Swedes are also relatively tall, with average male heights over 1.77 metres and

\footnotetext{
${ }^{11}$ In an attempt to control for other factors that might explain variation in cognitive function at older ages, we also included adult measures of social capital and physical activity as explanatory variables (we do not have early life indicators for these variables available). We also tried controlling for the proportion not working for pay as Rohwedder and Willis (2010) highlight that there is considerable cross-country variation in retirement policies in Europe and that this is related to cognitive functioning. However, even with these measures included in the model, the coefficient on height remains significant in our regressions.
} 
average female height over 1.64 metres. On the other hand, people from Spain and Italy are the shortest in our sample. Our results largely correspond with the historical European height data that is reported in Garcia and Quintana-Domeque (2007) and Hatton and Bray (2010).

[Figure 1 about here]

Figures 2 to 8 provide country averages of the five cognitive measures in order to highlight the raw differences across countries. There is considerable cross-country variation in most measures, such as numeracy (Figure 3), verbal fluency (Figure 4), immediate recall (Figure 5), delayed recall (Figure 6), reading skills (Figure 7) and writing skills (Figure 8). The sole exception is the average date score (Figure 2). But that lack of variation is easily explained - with most people scoring close to full marks for the test, there is simply not much room for cross-country variation. A casual glance at the figures suggests that height could be correlated with cognitive functioning, as countries with the shortest people - Italy and Spain - also tend to perform the most poorly on all cognitive measures. On the other hand, the Northern European countries with relatively taller people tend to score better on each test.

[Figures 2-8 about here]

In order to examine the cross-country relationship between height and each of the cognitive measures, we first regressed height and each of the cognitive outcomes on a full set of person-level covariates to control for people's different characteristics (see the list of covariates in Table 4) and country dummies. Table 6 presents the coefficients on the country dummies of the separately estimated regressions for each outcome, with Spain as the omitted reference country.

The correlations of the variables in Table 6 are presented in Table 7. We emphasize that these cross-country correlations that are based on country dummies reflect adjustments made for differences in individual level characteristics, and are not simply cross-country correlations of country averages. ${ }^{12}$ The latter is the approach most commonly taken when only aggregate country level data are available (e.g., in the empirical economic growth literature). Our approach of building up country level aggregates from micro-level data helps

\footnotetext{
12 This follows an approach used in Blanchflower and Oswald (2008) when jointly analyzing micro-level data from several different countries.
} 
us to better adjust for the different characteristics that people from different countries might have.

[Table 6 about here]

[Table 7 about here]

Our findings are striking. We had previously seen that there are strong positive associations between height and cognitive function in each of the 13 countries (Table 5). Here, we also find that countries with taller people have higher levels of cognitive function in our cross-country comparisons. High correlations can be found, in particular, for verbal fluency, immediate recall, and numeracy. While we report simple Pearson correlation coefficients in the first row of Table 7, it is arguable that more appropriate correlation measures rely only on the ordinality of the measures. We therefore also perform both Kendall's and Spearman's rank correlation tests. Kendall's tau statistic is particularly suitable for smaller data sets such as the SHARE data. Two-sided tests of the null hypothesis of no correlation between the country dummies suggest that at the five percent level, there are significant correlations between height and verbal fluency, height and immediate word recall, height and delayed word recall and height and numeracy. Plots of the cross-country relationships between height and the various measures of cognitive function are given in Figure 9, highlighting the positive correlation between height and cognitive function.

[Figure 9 about here]

In addition to performing the analysis at the country level, we also perform the analysis done in Table 7 and Figure 9 at the regional level defined by the Nomenclature of Units for Territorial Statistics (NUTS). We use the category of regions at the second level (NUTS2) that is commonly used by Eurostat, giving us 144 regions from the 13 countries in SHARE. Table 8 shows that correlations between height and the cognitive outcomes are also strong when the regional data are used, suggesting a geographical element in the link between height and cognitive ability.

[Table 8 about here] 


\section{Do Increases in Height have an Effect on Cognitive Outcomes?}

It has been noted by Martorell (1998) that recent gains in height in the 20th century have to some extent occurred in tandem with gains in intelligence scores. In order to go beyond stating that there is a correlation between height and cognitive outcomes, in this section, we perform an instrumental variables (IV) analysis in an attempt to shed some light on whether exogenous changes in height have a potentially causal effect on cognitive outcomes. As adult heights tend to reach their maximum and stabilize after puberty and tend to not be subject to large positive changes thereafter, finding a naturally occurring event that leads to changes in height for one group but not another appears to be a difficult task.

The basic difficulty with making a causal interpretation with the OLS regressions in Tables 4 and 5 is that it is likely that height is an endogenous variable. As discussed in Case and Paxson (2008a), both cognitive ability and height could be influenced by an unobserved factor that reflects the combined effects of environmental conditions (such as health and nutrition), biological factors, genetic factors or gene-environment interactions, a factor they refer to as an individual's endowment. In section 2.4, we highlighted studies which suggest that there might be factors unobservable to the econometrician that are related to both height and cognitive outcomes. In particular, Sundet et al. (2005) and Beauchamp et al. (2010) had found using data on twins that although the environment plays a large role and is responsible for 65 percent of the height-intelligence correlation, genes are still responsible for 35 percent of the observed correlation.

In this section, we exploit this naturally occurring variation in height trends among European countries due to nutritional deprivation in World War II in order to estimate the effects of height on cognitive outcomes. We expect that a nutritional shock during the critical early childhood years to have long term effects on both height and cognitive outcomes. For example, using experimental data from the Institute of Nutrition of Central America and Panama (INCAP) longitudinal study from 1969 to 1977, Maluccio et al. (2009) find that Guatemalan children who had been provided with nutrition supplements during the first three years of life were likely to be taller and scored higher on cognitive tests. ${ }^{13}$ We first provide evidence that wars disrupt the trend in the evolution of adult height by comparing height trends of war and non-war countries. Having established that war has adverse effects on adult height attainment, we then measure the change in cognitive outcomes in later life experienced by those individuals who did not achieve their full height potential because of the war. The

\footnotetext{
${ }^{13}$ For more on the specific details on the nutrient deficits that are associated with growth and cognitive deficits, see Fugelstad, Rao and Georgieff (2008).
} 
local average treatment effect (LATE) interpretation here is based on the framework of Imbens and Angrist (1994). In essence, we are measuring the average effect of an extra $1 \mathrm{~cm}$ of height on cognitive outcomes in later life for an individual who was shorter than his/her potential because of the war.

For the treatment group in our IV analysis, we focus on individuals born between 1939 and 1947. Although World War II started in September 1939 and ended in September 1945, we include birth cohorts till 1947 in the treatment group because of the widespread devastation in the early post-war period where food shortages were severe. In 1948, the Marshall Plan was introduced, which was a large scale American program to aid Europe to rebuild and regain its pre-war prosperity. European nations received billions of dollars in aid, which initially resulted in shipments of food, staples, fuel and machinery from the United States and later resulted in investment in industrial capacity in Europe. By 1952 as the funding ended, Eichengreen (2008) notes that the economy of every participant state had surpassed pre-war levels. For countries that were Marshall Plan recipients, output in 1951 was at least 35 percent higher than in 1938. For the comparison group, we focus on birth cohorts in the post-war period from 1948 to $1955 .^{14}$ The reason we focus on individuals born during or shortly after the war and not older individuals is because it is known that adverse factors experienced early in life could act to delay growth. Depending on the severity and duration of the inhibitory factor, adult height may also be affected (Li et al., 2004).

Assigning individuals to the treatment and comparison group based on the cohort dummy is not fully satisfactory because the cognitive outcomes in later ages of individuals born between 1939 and 1955 may have been influenced by several other factors that have nothing to do with the loss of potential stature due to the war. For example, cohort effects could arise as individuals born in the post-war period (i.e., the baby boomers) generally grew up in a time of affluence and world peace. These factors might have effects on cognitive outcomes that should not be confounded with the effects due to stature losses caused by the war.

In order to go beyond simply looking at a comparison across birth cohorts, we also compare individuals born between 1939 and 1955 in countries that participated in World War II (Austria, Germany, Netherlands, Italy, France, Denmark, Greece, Belgium, Czech Republic, Poland) and countries that were not participants in World War II (Spain, Sweden

\footnotetext{
${ }^{14}$ We use 1955 as the cutoff because samples sizes in SHARE are much smaller following the 1955 birth cohort.
} 
and Switzerland). ${ }^{15}$ Therefore, in our IV-LATE models, the assignment to treatment is defined as the intersection of the following two events: being born in a country that participated in World War II and being born between 1939 and 1947. The product of the two dummies denoting these conditions is the instrument for height. As in a related application in Ichino and Winter-Ebmer (2004), this specification has the conventional difference-indifference form, where country effects and cohort effects are eliminated. The LATE estimator should therefore give us the changes in cognitive outcomes of individuals who were potentially shorter because they were born between 1939 and 1947 and were born in a country that participated in World War II.

Figure 10 depicts the evolution of average height by year of birth in the war and nonwar countries. Over this period, all countries experienced an increase in height and educational attainment. From the left panel of Figure 10, however, there appears to be stagnation in the growing trend in average heights in the 1940s for the countries involved in the war whereas no stagnation is visible for non-war countries (right panel). It is this difference in height trends for war and non-war countries upon which our identification is based. The finding that war negatively affects height was also found by Alderman, Hoddinott and Kinsey (2006). Using data from Zimbabwe, they find that exposure to the late 1970s civil war in early childhood negatively affects height-for-age standardized $z$ scores.

[Figure 10 about here]

\subsection{IV-LATE Results}

In Table 9 we present OLS estimates and IV-LATE estimates obtained using the intersection of being born in a country that participated in World War II and being born between 1939 and 1947 as an instrument. As a robustness check, we also present alternative IV-LATE estimates defining individuals born between 1939 and 1948 as well as individuals born between 1939 and 1946 as treatment group members.

[Table 9 about here]

\footnotetext{
${ }^{15}$ Although Spain did not participate in World War II, it had a civil war from 1936-1939. To ensure that the Spaniards in our comparison group were not adversely affected by the civil war and its immediate post-war aftermath, we dropped any individuals born in Spain in the period 1939-1941.
} 
According to the OLS regressions, height is statistically significantly correlated with cognitive outcomes at later ages. These results are not sensitive to the set of covariates used and echo the results seen earlier in Table 4 where a similar analysis was performed (but where no age restrictions were made on the sample). The IV-LATE estimates, however, tell a very different story. In all cases, once the possible endogeneity of height is taken into account, the coefficient on height is no longer statistically significant and different from zero. In other words, although there is some evidence that the environmental deprivation caused by the war led individuals to become shorter (i.e., shorter than they otherwise would have been in the absence of the war), there were no adverse longer term effects on cognitive outcomes in later life. The finding that the IV-LATE estimates were not significant for the war countries as a whole suggests that a complete causal explanation for the association between height and cognitive outcomes likely lies beyond the nutritional channel. ${ }^{16}$ Although one might be tempted to use this as evidence that genetics play a key role, as highlighted by Currie (2011), this sharp distinction that is often made between "nature and nurture" is outdated and not helpful. Instead, the emerging science of epigenetics suggests that geneenvironment interactions are likely to be important. Currie (2011) surveys work in economics that demonstrates the malleability of health at birth, and concludes that "we cannot assume that differences that are present at birth reflect unchangeable genetic factors" (p. 33). For example, Heijmans et al. (2008) report finding that mothers who were pregnant during the Dutch famine (1944-1945) had altered the genetic material of embryos in the early stages of development, which was still discernible some sixty years later. These were not alterations in the genetic code, but a different setting for the code which indicates whether a gene is switched on or off.

One concern over using World War II as an instrument is that it is possible that the war effects work not only through height but also through education. Education disruption of children growing up during the war could have effects on cognitive outcomes in later ages that are independent of height. This would invalidate the use of our instrument as it would violate the exclusion restriction assumption of Angrist et al. (1996). This is a potentially serious concern. As Ichino and Winter-Ebmer (2004) argue, World War II disrupted the educational process making it harder for the population in schooling age to achieve the desired level of education. They therefore use the war as an instrument for schooling to get an IV estimate of the returns to education. However, it is important to note that their analysis

\footnotetext{
${ }^{16}$ Of course, one could also argue that our instruments are too weak to make such an interpretation.
} 
focuses only on the population in schooling age at the time of the war. Specifically, Ichino and Winter-Ebmer (2004) concentrate on persons who reached age 10 during or immediately after the war in their analysis because age 10 was (and still is) a crucial age for education decisions. At age 10, students decide whether or not to pursue a secondary school education, the only route to higher education. On the other hand, in our paper, by focusing on individuals below age 10 at the start or the end of the war period, we expect the disruption to education to be minimal compared to those over age 10. Indeed, looking at Figure 11, it is quite clear that the trend in educational attainment for individuals born in the 1940s is positive and smooth as compared to the trend in 1930-35, which corresponds to the birth cohorts Ichino and Winter-Ebmer (2004) focus on.

[Figure 11 about here]

Another assumption required in the IV-LATE model is that no one should be induced by the war environment to become taller and would instead be shorter if born in a non-war environment. It is very unlikely that this will be the case in our application as the conditions of war are clearly less conducive to physical well-being and growth. This monotonicity assumption ensures that the data can be informative on individuals who would be taller in the absence of the war constraint and shorter if constrained by the war.

\subsection{IV-LATE Results for Greece and the Netherlands}

Although countries involved in World War II all experienced widespread devastation and food shortages, from a nutritional viewpoint, people in Greece and the Netherlands likely suffered the most in terms of food shortages due to severe periods of famine. The Greek famine (1941-1942) was a period of mass starvation due to the German occupation of Greece during World War II (e.g., see Valaoras, 1946). Around the same time, there was also a severe Dutch famine in the winter of 1944 due to a German blockade of food shipments from farm areas where at the height of the famine from December 1944 to April 1945, the official daily adult rations varied between 400 and 800 calories. (e.g., see Stein et al., 1975). In Table 10, we therefore present the corresponding OLS and IV-LATE estimates for these two 
countries separately, while still using Spain, Sweden and Switzerland as comparison group countries. ${ }^{17}$

[Table 10 about here]

The results for the Netherlands mirror those for the war countries as a whole. The IVLATE estimates are all not statistically significant. Strikingly, however, the IV-LATE estimates for Greece are 8-12 times larger than the corresponding OLS estimates for three outcomes - reading skills, writing skills and immediate word recall. The LATE interpretation in this case would mean that the environmental deprivation in Greece caused by the war which led individuals to become shorter (than they otherwise would have been) had adverse longer term effects on them in terms of cognitive outcomes in later life. For example, an extra $10 \mathrm{~cm}$ in height would correspond to an increase of about 1.2-1.4 points in the immediate recall score. Given a Greek average of 4.78 (see Figure 5), this would represent about a 25-30 percent increase in the score. The instrument also seems particularly strong for Greece, where the first stage F-statistics are greater than 10, the criteria suggested by Staiger and Stock (1997) in distinguishing between strong and weak instruments. ${ }^{18}$

Why are there significant LATE effects for Greece but not in the Netherlands? One possible explanation is that the adverse conditions experienced in Greece during World War II exceeded that of the Netherlands. Although intense, the Dutch famine only lasted for five months. The finding that the Dutch famine had no significant effects on cognitive outcomes measured later in life has also been previously reported by other studies of the Dutch famine (e.g., Susser and Stein, 1994; De Groot et al., 2011). On the other hand, the 1940s was an extremely tumultuous period for the Greeks, with tensions between the leftists and rightists developing already while World War II was in progress and culminating in the Greek civil war which took place from 1946-1949.

\footnotetext{
${ }^{17}$ Although Germany also suffered a famine as a result of World War II, it was only after the war during the period 1945-1948 that there were severe food shortages in Germany. Therefore, as one might expect, the corresponding IV-LATE estimates for Germany (not shown) are not statistically significant as the period of the German famine sits in-between our treatment and control periods in our IV-LATE setup. Recent studies in economics that focus more directly on the effects of the famines in Europe during World War II on later life outcomes include Neelsen and Stratmann (2011) and Van den Berg et al. (2011).

${ }^{18}$ In order to alleviate the concern that our instrument might be invalid because World War II's effect on cognitive outcomes operates not only via height but also via education, in Table A.3 in the appendix, we provide IV-LATE estimates for Greece with and without years of education as a covariate. As the coefficient on height is largely not affected, this suggests that for the cohort we analyse in this paper, disruption to education due to the war was minimal.
} 
We speculate that another possible explanation is that the Dutch and Greek populations involve people at different spectrums in the height distribution. As can be seen in Figure 1, the Dutch are one of the tallest people in the world (males have an average height of 1.78 metres) whereas the Greeks are among the shorter populations in Europe (males have an average height of 1.72 metres). The concept of cognitive reserve has been proposed to account for the repeated observation that there does not appear to be a direct relationship between the degree of brain pathology and the clinical manifestation of that damage (e.g., Stern, 2002). ${ }^{19}$

In a recent paper, Brickman et al. (2011) propose height alongside other anthropometric measures of development as a measure of reserve. ${ }^{20}$ Consistent with the interpretation that the Dutch would be better equipped than the Greeks to deal with a famine shock because they are taller and had higher levels of cognitive reserve, Brickman et al. (2011) find that those with higher reserve had more pathology in the form of white matter hyperintensities (which is a marker of brain disease), suggesting that they are better able to cope with pathology than those with lower reserve.

In our context, perhaps it is the case that for people from a relatively tall population, losing one to two $\mathrm{cm}$ in potential height attainment might not matter as much compared to people from a shorter population. In other words, the interaction between lower levels of cognitive reserves and an extreme environmental shock can lead to large effects on cognitive functioning in later life.

\section{Conclusions}

Height has been used as a key marker of physical welfare and the standard of living, as well as a marker of childhood health. Previous research based on national surveys has found that height is correlated with cognitive function at older ages. Using data for 13 additional European countries, this paper provides further empirical support for the notion that there exist a significant association between height and cognitive function in later life.

In this paper, we also ask a related and interesting question: do people from countries where the average person is relatively tall have superior cognitive abilities? To our

\footnotetext{
${ }^{19}$ For example, autopsies of individuals with Alzheimer disease and those with normal brain aging reveal that in many instances, the two groups have similar levels of Alzheimer disease pathology in their brains at death. One possible explanation is that those with normal brain aging did not express clinical features of Alzheimer disease because they had a capacity that created a delay in time between pathology and its clinical expression. Those with a higher reserve can afford to sustain more pathological damage than others; it is hypothesized that only after the threshold has been reached will clinical expression of the pathology take place.

${ }^{20}$ Singh-Manoux et al. (2011) also use height as one of their indicators of cognitive reserve.
} 
knowledge, this paper is the first to explore the link between height and cross-country differences in cognitive functioning. Using data from the Survey of Health, Ageing, and Retirement in Europe, we find empirical evidence that this is the case, even after controlling for self-reported childhood health, self-reported childhood ability, parental characteristics and education. By focusing only on European countries, however, one shortcoming of our study is that it does not include Asian countries such as Korea and Japan. Given their economic success and high standards of living despite the general shorter stature of Asians, it is possible that the inclusion of Asian countries in our analysis will weaken the association between height and cognitive outcomes that we observe. This will be an interesting avenue for future research.

Exploiting variation in height trends in the middle of the twentieth century due to nutritional deprivation in World War II and using an instrumental variable analysis, we also provide suggestive evidence that the link from height to cognitive outcomes could be causal. In particular, the IV-LATE results on cognitive outcomes for Greece suggest that there could be a link between stature and cognitive ability. The finding that the IV-LATE estimates were not significant for the war countries as a whole, however, suggests that a complete causal explanation for the association between height and cognitive outcomes does not operate only via the nutritional channel.

In summary, the results of this paper suggest that average height is related to average measures of cognitive functioning, both within a country and also when comparing across countries. Previous cross-country analyses have focused on identifying important drivers of various national indicators of policy importance, such as economic development (e.g., Deaton, 2007; Hanushek and Woessman, 2008) and economic literacy (e.g., Jappelli, 2010). The results reported in this paper are suggestive of the role that height might play as a driver of policy related goals and the potential importance of ensuring that growth is maximized during childhood. It therefore highlights the use of height as a potentially useful national indicator. At present, height is not a statistic that is routinely collected during censuses but there appears to be good reasons why there is potential value in doing so.

\section{Acknowledgments}

This paper uses data from SHARE release 2.5.0 (May 24th 2011) and SHARELIFE release 1 (November 24th 2010). The SHARE data collection has been primarily funded by the European Commission through the $5^{\text {th }}, 6^{\text {th }}$ and $7^{\text {th }}$ framework programmes. Additional funding from the U.S. National Institute on Aging as well as from various national sources is gratefully acknowledged (see www.shareproject.org/t3/share/index.php for a full list of funding institutions). 


\section{References}

Alderman, H., J. Hoddinott and B. Kinsey. (2006). Long Term Consequences of Early Childhood Malnutrition. Oxford Economic Papers, 58: 450-474.

Allen, H., K. Estrada, G. Lettre al. (2010). Hundreds of Variants Clustered in Genomic Loci and Biological Pathways Affect Human Height. Nature, ;467:832-838.

Angrist, J., G. Imbens and D. Rubin. (2006). Identification of Causal Effects Using Instrumental Variables. Journal of the American Statistical Association, 91: 444-455.

Barber, N. (2005). Educational and Ecological Correlates of IQ: a Cross-National Investigation. Intelligence, 33: 273-284.

Beard, A. and M. Blaser. (2002). The Ecology of Height: The Effect of Microbial Transmission on Human Height. Perspectives Biology and Medicine, 45: 475-99.

Belmont, M. and F. Marolla. (1973). Birth Order, Family Size, and Intelligence. Science, 182: 1096-1101.

Beauchamp, A., D. Cesarini, M. Johannesson, E. Lindqvist and C. Apicella. (2010). On the Sources of the Height-Intelligence Correlation: New Insights from a Bivariate ACE Model with Assortative Mating. Behavioral Genetics. DOI 10.1007/s10519-010-9376-7.

Behrman, J, and M. Rosenzweig. (2004). Returns to Birthweight. Review of Economics and Statistics, 86: 586-601.

Black, S., P. Devereux and K. Salvanes. (2007a). From the Cradle to the Labor Market? The Effect of Birth Weight on Adult Outcomes. Quarterly Journal of Economics, 122: 409-439.

Black, S., P. Devereux and K. Salvanes. (2007b). Older and Wiser? Birth Order and IQ of Young Men. NBER Working Paper No. 13237. Cambridge: MA.

Blanchflower, D. and A. Oswald. (2008). Hypertension and Happiness Across Nations. Journal of Health Economics, 27: 218-233.

Börsch-Supan, A. and H. Jürges. (eds). (2005). The Survey of Health, Ageing and Retirement in Europe -Methodology. Mannheim: MEA.

Bozzoli, C., A. Deaton and C. Quintana-Domeque (2009). Adult Height and Childhood Disease. Demography, 46: 647-669.

Brickman, A., K. Siedlecki, Muraskin, J. Manly, J. Luchsinger, L. Yeung, T. Brown, C. DeCarli and Y. Stern. (2011). White Matter Hyperintensities and Cognition: Testing the Reserve Hypothesis. Neurobiology of Aging, 32: 1588-1598.

Case, A. and C. Paxson. (2008a). Stature and Status: Height, Ability, and Labor Market Outcomes. Journal of Political Economy, 116: 499-532. 
Case, A. and C. Paxson. (2008b). Height, Health and Cognitive Function at Older Ages. American Economic Review, 98: 463-467.

Case, A. and C. Paxson. (2010). Causes and Consequences of Early Life Health. Demography, 47: S65-S85.

Currie, J. (2011). Inequality at Birth: Some Causes and Consequences. American Economic Review, 101: 1-22.

Deaton, A. (2007). Height, Health, and Development. Proceedings of the National Academy of Sciences, 104: 13232-13237.

De Groot, L., S. Sette, G. Zajkas and A. Carbajal. (1991). Nutritional Status: Anthropometry. Euronut SENECA Investigators. European Journal of Clinical Nutrition, 45: 31-42.

De Groot, R., A. Stein, J. Jolles et al. (2011). Prenatal Famine Exposure and Cognition at 59 Years. International Journal of Epidemiology, 40: 327-337

Duncan G., J. Brooks-Gunn and P. Klebanov. (1994). Economic Deprivation and Early Childhood Development. Child Development, 65: 296-318.

Eichengreen, B. (2008). The European Economy since 1945: Coordinated Capitalism and Beyond. Princeton University Press: New Jersey.

Eppig, C., C. Fincher and R. Thornhill. (2010). Parasite Prevalence and the Worldwide Distribution of Cognitive Ability. Proceedings of the Royal Society B: Biological Sciences (doi:10.1098/rspb.2010.0973).

Eveleth, P. and J. Tanner. (1990). Worldwide Variation in Human Growth, 2nd edition (Cambridge: Cambridge University Press).

Everson-Rose, S., Mendes de Leon, C., Bienias, J., Wilson, R., Evans, D. (2003). Early Life Conditions and Cognitive Functioning in Later Life. American Journal of Epidemiology, 158: 1083-1089.

Fogel, R. (1993). New Sources and New Techniques for the Study of Secular Trends in Nutritional Status, Health, Mortality, and the Process of Aging. Historical Methods, 26: 5-43.

Fuglestad, A. R. Rao, M. Georgieff. (2008). The Role of Nutrition in Cognitive Development, in Handbook of Developmental Cognitive Neuroscience (Second Edition), C. Nelson and M. Luciana (eds.), MIT Press, Cambridge: Massachusetts.

Garcia, J. And C. Quintana-Domeque. (2007). The Evolution of Adult Height in Europe: a Brief Note. Economics and Human Biology, 5: 340-349.

Gelade, G. (2008). IQ, Cultural Values, and the Technological Achievement of Nations. Intelligence, 36: 711-718. 
Guven, C. and W. Lee. (2011). Height and Cognitive Function at Older Ages: Is Height a Useful Summary Measure of Early Childhood Experiences? Forthcoming in Health Economics.

Hanushek, E. and L. Woessmann. (2008). The Role of Cognitive Skills in Economic Development, Journal of Economic Literature, 46: 607-68.

Hatton, T and B. Bray. (2010). Long Run Trends in the Heights of European Men, 19th-20th centuries. Economics and Human Biology, 8: 405-413.

Heijmans, B., E. Tobi, A. Stein, H. Putter, G. Blauw, E. Susser, P. Slagboom and L. Lumey. (2008). Persistent Epigenetic Differences Associated with Prenatal Exposure to Famine in Humans. Proceedings of the National Academy of Sciences of the United States of America, 105: 17046-17049.

Heineck, G. (2009). Too Tall to be Smart? The Relationship between Height and Cognitive Abilities. Economics Letters, 105: 78-80.

Ichino, A. and R. Winter-Ebmer. (2004). The Long-Run Educational Cost of World War II. Journal of Labor Economics, 22: 57-86.

Imbens, G. and J. Angrist. (1994). Identification and Estimation of Local Average Treatment Effects, Econometrica, 62: 467-475.

Jappelli, T. (2010). Economic Literacy: An International Comparison. Economic Journal, 120: F429-F451.

Jensen, A. (1983). Effects of Inbreeding on Mental-Ability Factors. Personality and Individual Differences, 4: 71-87.

Jensen, A. and S. Sinha. (1993). Physical Correlates of Human Intelligence. In P. A. Vernon (Ed.), Biological Approaches to the Study of Human Intelligence (pp. 139-242). Norwood, NJ: Ablex.

Johnston, D., M. Nichols, M. Shah and M. Shields. (2009). Nature's Experiment? Handedness and Early Childhood Development. Demography, 46: 281-301.

Johnson, F. (1991). Biological Factors and Psychometric Intelligence: A Review. Genetic, Social, and General Psychology Monographs, 117: 313-357.

Kanazawa, S. and D. Reyniers. (2009). The Role of Height in the Sex Difference in Intelligence. American Journal of Psychology, 122: 527-536.

Kaplan G., G. Turrell, J. Lynch, S. Eversona, E. Helkalac and J. Salonenc. (2001). Childhood Socioeconomic Position and Cognitive Function in Adulthood. International Journal of Epidemiology, 30: 256-63.

Kretchmer, N., J. Beard and S. Carlson. (1996). The Role of Nutrition in the Development of Normal Cognition. American Journal of Clinical Nutrition, 63: 997S-1001S. 
Li, L., O. Manor O and C. Power. (2004). Early Environment and Child-to-Adult Growth Trajectories in the 1958 British Birth Cohort. American Journal of Clinical Nutrition, 80:185-92.

Li, L. and C. Power. (2004). Influences on Childhood Height: Comparing Two Generations in the 1958 British Birth Cohort. International Journal of Epidemiology, 33: 1320-1328.

Lynn, R. (1989). A Nutrition Theory of the Secular Increases in Intelligence, Positive Correlation between Height, Head Size and IQ. British Journal of Educational Psychology, 59: 372-77.

Lynn, R. (1990). The Role of Nutrition in Secular Increases in Intelligence, Personality and Individual Differences, 11: 273-286.

Lynn, R. (1991). The Evolution of Racial Differences in Intelligence. Mankind Quarterly, 32: 99-121.

Maluccio, J., J. Hoddinott, J. Behrman, R. Martorell, A. Quisumbing, A. Stein. (2009). The Impact of Improving Nutrition During Early Childhood on Education among Guatemalan Adults. Economic Journal, 119: 734-763.

Martorell, R. (1998). Nutrition and the Worldwide Rise in IQ. In U. Neisser (Ed.), The Rising Curve. Long Term Gains in IQ and Related Measures (pp. 183-206). Washington, DC: American Psychological Association.

Maurer, J. (2010). Height, Education and Cognitive Function at Older Ages: International Evidence from Latin America and the Caribbean. Economics and Human Biology, 8: 168176.

Neelsen, S. and T. Stratmann. (2011). Effects of Prenatal and Early Life Malnutrition: Evidence from the Greek famine. Journal of Health Economics, 30: 479-488.

Palta, M., R. Prineas, R. Berman and P. Hannan. (1982). Comparison of Self-Reported and Measured Height and Weight. American Journal of Epidemiology, 115: 223-230.

Peck, A. and O. Lundberg. (1995). Short Stature as an Effect of Economic and Social Conditions in Childhood. Social Science and Medicine, 41: 733-738.

Rodgers, J., H. Harrington, E. Van den Oord and D. Rowe. (2000). Resolving the Debate over Birth Order, Family Size and Intelligence. American Psychologist, 55: 599-612.

Rohwedder, S. and R. Willis. (2010). Mental Retirement. Journal of Economic Perspectives, 24: 119-138.

Rushton, J. (1995). Race, Evolution, and Behavior: a Life History Perspective. New Brunswick, NJ: Transaction.

Saadat, M. (2008). Consanguinity and National IQ Scores. Journal of Epidemiology and Community Health, 62: 566-567. 
Schick, A. and R. Steckel. (2010). Height as a Proxy for Cognitive and Non-Cognitive Ability. NBER Working Paper No. 16570.

Silventoinen, K. (2003). Determinants of Variation in Adult Body Height. Journal of Biosocial Science, 35: 263-285.

Silventoinen, K., D. Posthuma, T. van Beijsterveldt, M. Bartels and D. Boomsma. (2006). Genetic Contributions to the Association between Height and Intelligence: Evidence from Dutch Twin Data from Childhood to Middle Age. Genes, Brain and Behavior, 5: 585-595.

Singh-Manoux, A., M. Marmot, M. Glymour, S. Sabia, M. Kivimäki and A. Dugravot. (2011). Does Cognitive Reserve Shape Cognitive Decline? Annals of Neurology, 70: 296304.

Smith, J. (2009). Reconstructing Childhood Health Histories. Demography, 46: 387-403.

Staiger, D. and J. Stock. (1997). Instrumental Variables Regression with Weak Instruments. Econometrica, 65: 557-586.

Steckel, R. (1995). Stature and the Standard of Living. Journal of Economic Literature, 33: 1903-1940.

Steckel, R. (2009). Heights and Human Welfare: Recent Developments and New Directions. Explorations in Economic History, 46: 1-23.

Stein, Z., M. Susser, G. Saenger and F. Marolla. (1975). Famine and Human Development: The Dutch Hunger Winter of 1944-1945. New York: Oxford University Press.

Stern, Y. (2002). What is Cognitive Reserve? Theory and Research Application of the Reserve Concept. Journal of the International Neuropsychological Society, 8: 448-460.

Steward, A. (1982). The Reliability and Validity of Self-Reported Weight and Height. Journal of Chronic Diseases, 35: 295-309.

Sundet J., K. Tambs., J. Harris, P. Magnus and T. Torjussen. (2005). Resolving the Genetic and Environmental Sources of the Correlation between Height and Intelligence: A Study of Nearly 2600 Norwegian Male Twin Pairs. Twin Research and Human Genetics, 8: 307-311.

Susser, M. and Z. Stein. (1994). Timing in Prenatal Nutrition: A Reprise of the Dutch Famine Study, Nutrition Reviews, 52:84-94.

Templer, D. and H. Arikawa. (2006). Temperature, Skin Color, Per Capita Income, and IQ: an International Perspective. Intelligence, 34: 121-139.

Valaoras, V. (1946). Some Effects of Famine on the Population of Greece. Milbank Memorial Fund Quarterly, 24: 215-234.

Van den Berg, G., D. Deeg, M. Lindeboom and F. Portrait. (2010). The Role of Early-Life Conditions in the Cognitive Decline due to Adverse Events Later in Life. Economic Journal, 120: F411-F428. 
Van den Berg, G., P. Pinger and J. Schoch. (2011). Instrumental Variable Estimation of the Causal Effect of Hunger Early in Life on Health Later in Life. IZA Discussion Paper No. 6110.

Woodley, M. (2009). Inbreeding Depression and IQ in a Study of 72 Countries. Intelligence, 37: 268-276.

Zhang, Z., D. Gu, and M. Hayward. (2008). Early Life Influences on Cognitive Impairment Among Oldest Old Chinese. Journal of Gerontology, 63B: S25-S33. 
Table 1: Summary Statistics

\begin{tabular}{|c|c|c|c|c|}
\hline Variable & Mean & $\begin{array}{c}\text { Standard } \\
\text { Deviation }\end{array}$ & Minimum & Maximum \\
\hline Age & 65.23 & 10.10 & 50 & 104 \\
\hline Male & 0.45 & 0.50 & 0 & 1 \\
\hline Reading skill & 3.64 & 1.14 & 1 & 5 \\
\hline Writing skill & 3.51 & 1.19 & 1 & 5 \\
\hline Dates score & 3.81 & 0.54 & 0 & 4 \\
\hline Verbal fluency & 18.89 & 7.56 & 0 & 100 \\
\hline Immediate recall & 4.89 & 1.85 & 0 & 10 \\
\hline Delayed recall & 3.43 & 2.03 & 0 & 10 \\
\hline Numeracy score & 0.62 & 0.24 & 0 & 1 \\
\hline Height & 167.96 & 8.99 & 100.68 & 210 \\
\hline Years of education & 10.08 & 4.15 & 0 & 25 \\
\hline ISCED category & 2.07 & 0.89 & 1 & 5 \\
\hline Childhood health & 3.95 & 1.01 & 1 & 5 \\
\hline Fathers prestige & 0.25 & 0.43 & 0 & 1 \\
\hline Childhood math ability & 3.29 & 0.90 & 1 & 5 \\
\hline Childhood language ability & 3.31 & 0.87 & 1 & 5 \\
\hline Childhood books at home & 2.04 & 1.20 & 1 & 5 \\
\hline Parents smoked & 0.63 & 0.48 & 0 & 1 \\
\hline Parents drank heavily & 0.08 & 0.27 & 0 & 1 \\
\hline Parents have mental health problems & 0.02 & 0.15 & 0 & 1 \\
\hline Mother present at home & 0.96 & 0.19 & 0 & 1 \\
\hline Father present at home & 0.91 & 0.28 & 0 & 1 \\
\hline Dwelling with no features & 0.28 & 0.45 & 0 & 1 \\
\hline Dwelling with $>3$ rooms & 0.48 & 0.50 & 0 & 1 \\
\hline Dwelling with $>4$ people & 0.64 & 0.48 & 0 & 1 \\
\hline Birth order & 2.06 & 0.84 & 1 & 3 \\
\hline Right handed & 0.93 & 0.25 & 0 & 1 \\
\hline
\end{tabular}

Notes: SHARE waves 1-3 are used covering the years 2002-2008 for 13 European countries.

Table 2: Pooled Country Regressions on Cognitive Outcomes

\begin{tabular}{|c|c|c|c|c|c|c|c|}
\hline & $\begin{array}{c}\text { Reading } \\
\text { skill } \\
(1) \\
\end{array}$ & $\begin{array}{c}\text { Writing } \\
\text { skill } \\
(2) \\
\end{array}$ & $\begin{array}{c}\text { Date } \\
\text { questions } \\
\text { score } \\
(3)\end{array}$ & $\begin{array}{c}\text { Verbal } \\
\text { fluency } \\
(4) \\
\end{array}$ & $\begin{array}{c}\text { Immediate } \\
\text { recall } \\
\text { score } \\
(5) \\
\end{array}$ & $\begin{array}{l}\text { Delayed } \\
\text { recall } \\
\text { score } \\
(6) \\
\end{array}$ & $\begin{array}{c}\text { Numeracy } \\
\text { test score } \\
(7)\end{array}$ \\
\hline Height $(\mathrm{cm})$ & $\begin{array}{l}0.014^{* *} \\
(16.89)\end{array}$ & $\begin{array}{l}0.015^{* *} \\
(16.71)\end{array}$ & $\begin{array}{l}0.002^{\text {*** }} \\
(4.24)\end{array}$ & $\begin{array}{l}0.073^{* *} \\
(14.67)\end{array}$ & $\begin{array}{l}0.016^{\text {*** }} \\
(12.84)\end{array}$ & $\begin{array}{l}0.018^{* * *} \\
(12.73)\end{array}$ & $\begin{array}{l}0.003^{* *} \\
(16.92)\end{array}$ \\
\hline Age & $\begin{array}{c}0.018^{* * *} \\
(2.66)\end{array}$ & $\begin{array}{c}0.022^{* * *} \\
(3.16)\end{array}$ & $\begin{array}{l}0.082^{* * *} \\
(17.48)\end{array}$ & $\begin{array}{c}0.173^{* * *} \\
(4.37)\end{array}$ & $\begin{array}{l}0.111^{* * *} \\
(11.81)\end{array}$ & $\begin{array}{c}0.064^{* *} \\
(6.41)\end{array}$ & $\begin{array}{l}0.006^{* *} \\
(4.48)\end{array}$ \\
\hline $\mathrm{Age}^{2} / 100$ & $\begin{array}{c}-0.034^{* * *} \\
(-6.67)\end{array}$ & $\begin{array}{c}-0.039^{* * *} \\
(-7.63)\end{array}$ & $\begin{array}{l}-0.070^{* * *} \\
(-19.13)\end{array}$ & $\begin{array}{l}-0.294^{* *} \\
(-10.06)\end{array}$ & $\begin{array}{l}-0.132^{* *} \\
(-18.98)\end{array}$ & $\begin{array}{l}-0.101^{* *} \\
(-13.77)\end{array}$ & $\begin{array}{c}-0.008^{* *} \\
(-7.73)\end{array}$ \\
\hline Male & $\begin{array}{l}-0.169^{* *} \\
(-11.76)\end{array}$ & $\begin{array}{l}-0.195^{* * *} \\
(-13.02)\end{array}$ & $\begin{array}{c}-0.034^{* * *} \\
(-5.06)\end{array}$ & $\begin{array}{c}-0.305^{* *} \\
(-3.61)\end{array}$ & $\begin{array}{l}-0.380^{* * *} \\
(-18.33)\end{array}$ & $\begin{array}{l}-0.509^{* *} \\
(-21.83)\end{array}$ & $\begin{array}{l}0.034^{* *} \\
(11.75)\end{array}$ \\
\hline Observations & 37518 & 37517 & 53778 & 53612 & 53893 & 53910 & 53202 \\
\hline R-squared & 0.202 & 0.199 & 0.086 & 0.275 & 0.248 & 0.223 & 0.139 \\
\hline
\end{tabular}

Notes: $t$-statistics are reported in parentheses together with the coefficients which are estimated using OLS. Height is in $\mathrm{cm}$. Standard errors are clustered at the individual level. SHARE waves 1-3 are used covering the years 2002-2008 for 13 European countries. Wave dummies and country dummies are included in all regressions. 
Table 3: Pooled Country Regressions on Cognitive Outcomes including Childhood and Mid-life Circumstances

\begin{tabular}{|c|c|c|c|c|c|c|c|c|}
\hline & $\begin{array}{c}\text { Height } \\
(\mathrm{cm}) \\
(1) \\
\end{array}$ & $\begin{array}{c}\begin{array}{c}\text { Reading } \\
\text { skill }\end{array} \\
(2) \\
\end{array}$ & $\begin{array}{c}\begin{array}{c}\text { Writing } \\
\text { skill }\end{array} \\
(3) \\
\end{array}$ & $\begin{array}{c}\text { Date } \\
\text { questions } \\
\text { score } \\
(4) \\
\end{array}$ & $\begin{array}{c}\text { Verbal } \\
\text { fluency } \\
(5) \\
\end{array}$ & $\begin{array}{c}\text { Immediate } \\
\text { recall } \\
\text { score } \\
(6) \\
\end{array}$ & $\begin{array}{c}\text { Delayed } \\
\text { recall } \\
\text { score } \\
(7) \\
\end{array}$ & $\begin{array}{c}\text { Numeracy } \\
\text { test score } \\
(8)\end{array}$ \\
\hline Height $(\mathrm{cm})$ & & $\begin{array}{l}0.008^{* * *} \\
(10.05)\end{array}$ & $\begin{array}{l}0.008^{* *} \\
(9.44)\end{array}$ & $\begin{array}{l}0.001^{* *} \\
(2.68)\end{array}$ & $\begin{array}{l}0.046^{* * *} \\
(9.49)\end{array}$ & $\begin{array}{l}0.009^{* * *} \\
(7.57)\end{array}$ & $\begin{array}{l}0.011^{* *} \\
(8.06)\end{array}$ & $\begin{array}{l}0.002^{* *} \\
(11.81)\end{array}$ \\
\hline Father white collar job & $\begin{array}{l}1.198^{* *} \\
(11.82)\end{array}$ & $\begin{array}{l}0.183^{* * *} \\
(12.46)\end{array}$ & $\begin{array}{l}0.195^{* *} \\
(12.65)\end{array}$ & $\begin{array}{l}-0.005 \\
(-0.98)\end{array}$ & $\begin{array}{l}0.861^{* * *} \\
(9.32)\end{array}$ & $\begin{array}{l}0.179^{* * *} \\
(8.27)\end{array}$ & $\begin{array}{l}0.187^{* * *} \\
(7.28)\end{array}$ & $\begin{array}{l}0.023^{* * *} \\
(7.77)\end{array}$ \\
\hline Childhood health & $\begin{array}{c}0.119^{* * *} \\
(2.64)\end{array}$ & $\begin{array}{l}0.069^{* * *} \\
(10.33)\end{array}$ & $\begin{array}{l}0.073^{* * *} \\
(10.73)\end{array}$ & $\begin{array}{l}0.006^{*} \\
(2.35)\end{array}$ & $\begin{array}{c}0.121^{* * *} \\
(3.19)\end{array}$ & $\begin{array}{l}0.020^{*} \\
(2.11)\end{array}$ & $\begin{array}{l}-0.004 \\
(-0.40)\end{array}$ & $\begin{array}{l}0.005^{* * *} \\
(3.55)\end{array}$ \\
\hline Years of schooling & & $\begin{array}{l}0.088^{* * *} \\
(58.77)\end{array}$ & $\begin{array}{l}0.098^{* * *} \\
(62.81)\end{array}$ & $\begin{array}{l}0.009^{* * *} \\
(13.61)\end{array}$ & $\begin{array}{l}0.377^{* * *} \\
(39.18)\end{array}$ & $\begin{array}{l}0.096^{* *} \\
(42.08)\end{array}$ & $\begin{array}{l}0.095^{* * *} \\
(36.26)\end{array}$ & $\begin{array}{l}0.013^{* * *} \\
(42.77)\end{array}$ \\
\hline Controls in Table 2 & Yes & Yes & Yes & Yes & Yes & Yes & Yes & Yes \\
\hline $\begin{array}{l}\text { Observations } \\
\text { R-squared }\end{array}$ & $\begin{array}{l}54705 \\
0.508\end{array}$ & $\begin{array}{l}37518 \\
0.291\end{array}$ & $\begin{array}{l}37517 \\
0.298\end{array}$ & $\begin{array}{l}53778 \\
0.094\end{array}$ & $\begin{array}{l}53612 \\
0.314\end{array}$ & $\begin{array}{l}53893 \\
0.289\end{array}$ & $\begin{array}{c}53910 \\
0.256\end{array}$ & $\begin{array}{l}53202 \\
0.183\end{array}$ \\
\hline
\end{tabular}

Notes: $t$-statistics are reported in parentheses together with the coefficients which are estimated using OLS. Height is in $\mathrm{cm}$. Standard errors are clustered at the individual level. SHARE waves 1-3 are used covering the years 2002-2008 for 13 European countries. Wave dummies and country dummies are included in all regressions. 
Table 4: Pooled Country Regressions on Cognitive Outcomes including Childhood History

\begin{tabular}{|c|c|c|c|c|c|c|c|c|}
\hline & $\begin{array}{c}\text { Height } \\
(\mathrm{cm}) \\
(1)\end{array}$ & $\begin{array}{c}\text { Reading } \\
\text { skill }\end{array}$ & $\begin{array}{c}\text { Writing } \\
\text { skill } \\
(3)\end{array}$ & $\begin{array}{c}\text { Date } \\
\text { questions } \\
\text { score } \\
(4)\end{array}$ & $\begin{array}{c}\text { Verbal } \\
\text { fluency } \\
(5)\end{array}$ & $\begin{array}{c}\text { Immediate } \\
\text { recall } \\
\text { score } \\
(6)\end{array}$ & $\begin{array}{c}\text { Delayed } \\
\text { recall } \\
\text { score } \\
(7)\end{array}$ & $\begin{array}{c}\text { Numeracy } \\
\text { test score } \\
\text { (8) }\end{array}$ \\
\hline Height $(\mathrm{cm})$ & & $\begin{array}{l}0.008^{* *} \\
(9.50)\end{array}$ & $\begin{array}{l}0.007^{* *} \\
(8.77)\end{array}$ & $\begin{array}{l}0.001^{* *} \\
(2.60)\end{array}$ & $\begin{array}{l}0.041^{* * *} \\
(8.60)\end{array}$ & $\begin{array}{l}0.008^{* *} \\
(6.93)\end{array}$ & $\begin{array}{l}0.010^{* *} \\
(7.40)\end{array}$ & $\begin{array}{l}0.002^{* *} \\
(10.96)\end{array}$ \\
\hline Childhood math ability & $\begin{array}{c}0.183^{* * *} \\
(3.27)\end{array}$ & $\begin{array}{c}0.037^{* *} \\
(4.69)\end{array}$ & $\begin{array}{c}0.046^{* *} \\
(5.56)\end{array}$ & $\begin{array}{l}0.013^{* *} \\
(4.21)\end{array}$ & $\begin{array}{l}0.557^{* * *} \\
(11.63)\end{array}$ & $\begin{array}{l}0.091^{* * *} \\
(8.06)\end{array}$ & $\begin{array}{c}0.121^{* *} \\
(8.81)\end{array}$ & $\begin{array}{l}0.035^{* * *} \\
(22.45)\end{array}$ \\
\hline $\begin{array}{l}\text { Childhood language } \\
\text { ability }\end{array}$ & $\begin{array}{l}0.085 \\
(1.46)\end{array}$ & $\begin{array}{l}0.204^{* * *} \\
(24.30)\end{array}$ & $\begin{array}{l}0.229^{* * *} \\
(26.06)\end{array}$ & $\begin{array}{l}0.004 \\
(1.33)\end{array}$ & $\begin{array}{l}0.382^{* * *} \\
(7.57)\end{array}$ & $\begin{array}{l}0.134^{* * *} \\
(11.16)\end{array}$ & $\begin{array}{l}0.127^{* * *} \\
(8.83)\end{array}$ & $\begin{array}{l}0.004^{*} \\
(2.51)\end{array}$ \\
\hline Childhood books at home & $\begin{array}{c}0.367^{* *} \\
(8.39)\end{array}$ & $\begin{array}{c}0.029^{* * *} \\
(4.62)\end{array}$ & $\begin{array}{l}0.034^{* *} \\
(5.20)\end{array}$ & $\begin{array}{l}-0.004 \\
(-1.82)\end{array}$ & $\begin{array}{l}0.597^{* *} \\
(15.26)\end{array}$ & $\begin{array}{l}0.064^{* *} \\
(6.96)\end{array}$ & $\begin{array}{c}0.080^{* * *} \\
(7.33)\end{array}$ & $\begin{array}{l}0.008^{* * *} \\
(6.61)\end{array}$ \\
\hline Parents smoked & $\begin{array}{l}-0.021 \\
(-0.22)\end{array}$ & $\begin{array}{l}0.001 \\
(0.05)\end{array}$ & $\begin{array}{l}-0.010 \\
(-0.71)\end{array}$ & $\begin{array}{l}-0.011 \\
(-1.93)\end{array}$ & $\begin{array}{l}0.132 \\
(1.69)\end{array}$ & $\begin{array}{l}-0.003 \\
(-0.15)\end{array}$ & $\begin{array}{l}0.001 \\
(0.05)\end{array}$ & $\begin{array}{l}-0.003 \\
(-1.21)\end{array}$ \\
\hline Parents drank heavily & $\begin{array}{l}-0.455^{* *} \\
(-2.77)\end{array}$ & $\begin{array}{l}-0.018 \\
(-0.76)\end{array}$ & $\begin{array}{l}-0.024 \\
(-0.98)\end{array}$ & $\begin{array}{l}-0.029^{* *} \\
(-2.74)\end{array}$ & $\begin{array}{l}-0.139 \\
(-1.01)\end{array}$ & $\begin{array}{l}-0.068^{*} \\
(-2.04)\end{array}$ & $\begin{array}{l}-0.045 \\
(-1.15)\end{array}$ & $\begin{array}{l}-0.014^{* *} \\
(-3.09)\end{array}$ \\
\hline $\begin{array}{l}\text { Parents have mental } \\
\text { health problems }\end{array}$ & $\begin{array}{l}-0.736^{*} \\
(-2.45)\end{array}$ & $\begin{array}{l}-0.061 \\
(-1.49)\end{array}$ & $\begin{array}{l}-0.085^{*} \\
(-1.97)\end{array}$ & $\begin{array}{l}-0.027 \\
(-1.68)\end{array}$ & $\begin{array}{c}0.474 \\
(1.81)\end{array}$ & $\begin{array}{l}-0.003 \\
(-0.04)\end{array}$ & $\begin{array}{l}-0.007 \\
(-0.10)\end{array}$ & $\begin{array}{l}-0.023^{* *} \\
(-2.69)\end{array}$ \\
\hline Mother present at home & $\begin{array}{l}0.342 \\
(1.37)\end{array}$ & $\begin{array}{l}-0.026 \\
(-0.74)\end{array}$ & $\begin{array}{l}0.016 \\
(0.45)\end{array}$ & $\begin{array}{l}-0.003 \\
(-0.22)\end{array}$ & $\begin{array}{l}-0.235 \\
(-1.08)\end{array}$ & $\begin{array}{l}0.002 \\
(0.04)\end{array}$ & $\begin{array}{l}-0.005 \\
(-0.08)\end{array}$ & $\begin{array}{l}-0.003 \\
(-0.50)\end{array}$ \\
\hline Father present at home & $\begin{array}{l}0.334 \\
(1.89)\end{array}$ & $\begin{array}{l}0.003 \\
(0.11)\end{array}$ & $\begin{array}{l}0.016 \\
(0.65)\end{array}$ & $\begin{array}{l}0.018 \\
(1.60)\end{array}$ & $\begin{array}{l}-0.138 \\
(-0.93)\end{array}$ & $\begin{array}{l}0.003 \\
(0.08)\end{array}$ & $\begin{array}{l}0.017 \\
(0.41)\end{array}$ & $\begin{array}{l}0.014^{* * *} \\
(2.74)\end{array}$ \\
\hline Dwelling with no features & $\begin{array}{l}-0.209 \\
(-1.88)\end{array}$ & $\begin{array}{l}-0.038^{*} \\
(-2.37)\end{array}$ & $\begin{array}{l}-0.039^{*} \\
(-2.34)\end{array}$ & $\begin{array}{l}0.013 \\
(1.75)\end{array}$ & $\begin{array}{l}-0.052 \\
(-0.59)\end{array}$ & $\begin{array}{c}-0.081^{* *} \\
(-3.57)\end{array}$ & $\begin{array}{l}-0.055^{*} \\
(-2.05)\end{array}$ & $\begin{array}{l}-0.003 \\
(-0.82)\end{array}$ \\
\hline Dwelling with $>3$ rooms & $\begin{array}{l}0.250^{*} \\
(2.50)\end{array}$ & $\begin{array}{l}-0.015 \\
(-1.04)\end{array}$ & $\begin{array}{l}-0.009 \\
(-0.58)\end{array}$ & $\begin{array}{l}0.001 \\
(0.20)\end{array}$ & $\begin{array}{c}0.302^{* * *} \\
(3.61)\end{array}$ & $\begin{array}{l}0.028 \\
(1.40)\end{array}$ & $\begin{array}{l}-0.034 \\
(-1.44)\end{array}$ & $\begin{array}{l}0.006^{*} \\
(2.18)\end{array}$ \\
\hline Dwelling with $>4$ people & $\begin{array}{c}-0.327^{* *} \\
(-3.27)\end{array}$ & $\begin{array}{l}0.011 \\
(0.81)\end{array}$ & $\begin{array}{l}0.008 \\
(0.53)\end{array}$ & $\begin{array}{l}0.008 \\
(1.36)\end{array}$ & $\begin{array}{l}-0.018 \\
(-0.21)\end{array}$ & $\begin{array}{l}-0.025 \\
(-1.20)\end{array}$ & $\begin{array}{l}-0.026 \\
(-1.07)\end{array}$ & $\begin{array}{l}-0.003 \\
(-0.97)\end{array}$ \\
\hline In-between child & $\begin{array}{l}-0.134 \\
(-1.46)\end{array}$ & $\begin{array}{c}-0.043^{* * *} \\
(-3.28)\end{array}$ & $\begin{array}{c}-0.049^{* * *} \\
(-3.64)\end{array}$ & $\begin{array}{l}-0.008 \\
(-1.30)\end{array}$ & $\begin{array}{c}-0.259^{* *} \\
(-3.21)\end{array}$ & $\begin{array}{l}-0.013 \\
(-0.65)\end{array}$ & $\begin{array}{l}-0.011 \\
(-0.51)\end{array}$ & $\begin{array}{l}-0.006^{*} \\
(-2.23)\end{array}$ \\
\hline Youngest child & $\begin{array}{c}-0.396^{* *} \\
(-4.45)\end{array}$ & $\begin{array}{c}-0.103^{* * *} \\
(-8.01)\end{array}$ & $\begin{array}{c}-0.100^{* * *} \\
(-7.53)\end{array}$ & $\begin{array}{l}-0.011 \\
(-1.72)\end{array}$ & $\begin{array}{l}-0.207^{* * *} \\
(-2.64)\end{array}$ & $\begin{array}{l}-0.040^{*} \\
(-2.14)\end{array}$ & $\begin{array}{l}-0.035 \\
(-1.59)\end{array}$ & $\begin{array}{l}-0.016^{* * *} \\
(-6.00)\end{array}$ \\
\hline Right handed & $\begin{array}{l}0.217 \\
(1.63)\end{array}$ & $\begin{array}{l}0.037 \\
(1.81)\end{array}$ & $\begin{array}{l}0.063^{* * *} \\
(2.98)\end{array}$ & $\begin{array}{l}0.021^{*} \\
(2.41)\end{array}$ & $\begin{array}{l}0.258^{*} \\
(2.22)\end{array}$ & $\begin{array}{l}0.063^{*} \\
(2.16)\end{array}$ & $\begin{array}{l}0.078^{*} \\
(2.33)\end{array}$ & $\begin{array}{l}-0.000 \\
(-0.10)\end{array}$ \\
\hline Controls in Table 3 & Yes & Yes & Yes & Yes & Yes & Yes & Yes & Yes \\
\hline $\begin{array}{l}\text { Observations } \\
\text { R-squared }\end{array}$ & $\begin{array}{l}54705 \\
0.511\end{array}$ & $\begin{array}{l}37518 \\
0.317\end{array}$ & $\begin{array}{l}37517 \\
0.328\end{array}$ & $\begin{array}{c}53778 \\
0.105\end{array}$ & $\begin{array}{c}53612 \\
0.331\end{array}$ & $\begin{array}{l}53893 \\
0.305\end{array}$ & $\begin{array}{c}53910 \\
0.267\end{array}$ & $\begin{array}{l}53202 \\
0.201\end{array}$ \\
\hline
\end{tabular}

Notes: $t$-statistics are reported in parentheses together with the coefficients which are estimated using OLS.

Height is in $\mathrm{cm}$. Standard errors are clustered at the individual level. SHARE waves 1-3 are used covering the years 2002-2008 for 13 European countries. Wave dummies and country dummies are included in all regressions. 
Table 5: Coefficient on Height for each of the 13 European Countries

\begin{tabular}{|c|c|c|c|c|c|c|c|}
\hline & $\begin{array}{c}\text { Reading } \\
\text { skill } \\
(1) \\
\end{array}$ & $\begin{array}{c}\text { Writing } \\
\text { skill } \\
(2)\end{array}$ & $\begin{array}{c}\text { Date } \\
\text { questions } \\
\text { score } \\
(3)\end{array}$ & $\begin{array}{c}\text { Verbal } \\
\text { fluency } \\
(4) \\
\end{array}$ & $\begin{array}{c}\text { Immediate } \\
\text { recall } \\
\text { score } \\
(5)\end{array}$ & $\begin{array}{c}\text { Delayed } \\
\text { recall } \\
\text { score } \\
(6)\end{array}$ & $\begin{array}{c}\text { Numeracy } \\
\text { test score } \\
\text { (7) }\end{array}$ \\
\hline Austria & $\begin{array}{l}0.010^{* * *} \\
(2.90)\end{array}$ & $\begin{array}{c}0.014^{* * *} \\
(3.74)\end{array}$ & $\begin{array}{l}0.002 \\
(1.51)\end{array}$ & $\begin{array}{c}0.077^{* *} \\
(2.71)\end{array}$ & $\begin{array}{l}0.022^{* *} \\
(3.45)\end{array}$ & $\begin{array}{c}0.020^{* *} \\
(2.73)\end{array}$ & $\begin{array}{c}0.002^{* *} \\
(2.61)\end{array}$ \\
\hline Germany & $\begin{array}{l}0.005^{*} \\
(2.03)\end{array}$ & $\begin{array}{l}0.006^{*} \\
(2.27)\end{array}$ & $\begin{array}{l}0.002 \\
(1.47)\end{array}$ & $\begin{array}{l}0.031 \\
(1.78)\end{array}$ & $\begin{array}{l}0.005 \\
(1.10)\end{array}$ & $\begin{array}{l}0.005 \\
(1.16)\end{array}$ & $\begin{array}{c}0.002^{* * *} \\
(4.03)\end{array}$ \\
\hline Sweden & $\begin{array}{l}0.009^{* * *} \\
(3.67)\end{array}$ & $\begin{array}{c}0.009^{* * *} \\
(3.57)\end{array}$ & $\begin{array}{l}-0.000 \\
(-0.49)\end{array}$ & $\begin{array}{l}0.021 \\
(1.20)\end{array}$ & $\begin{array}{l}0.002 \\
(0.45)\end{array}$ & $\begin{array}{l}0.001 \\
(0.23)\end{array}$ & $\begin{array}{l}0.001^{*} \\
(2.52)\end{array}$ \\
\hline Netherlands & $\begin{array}{l}0.004 \\
(1.73)\end{array}$ & $\begin{array}{l}0.005^{*} \\
(1.97)\end{array}$ & $\begin{array}{l}0.000 \\
(0.16)\end{array}$ & $\begin{array}{c}0.040^{* * *} \\
(2.89)\end{array}$ & $\begin{array}{l}-0.001 \\
(-0.20)\end{array}$ & $\begin{array}{l}0.004 \\
(0.87)\end{array}$ & $\begin{array}{c}0.002^{* *} \\
(3.64)\end{array}$ \\
\hline Spain & $\begin{array}{c}0.012^{* * *} \\
(4.69)\end{array}$ & $\begin{array}{c}0.009^{* * *} \\
(3.40)\end{array}$ & $\begin{array}{l}0.003 \\
(1.47)\end{array}$ & $\begin{array}{l}0.020 \\
(1.48)\end{array}$ & $\begin{array}{c}0.015^{* *} \\
(3.75)\end{array}$ & $\begin{array}{c}0.018^{* * *} \\
(4.43)\end{array}$ & $\begin{array}{c}0.002^{* * *} \\
(3.47)\end{array}$ \\
\hline Italy & $\begin{array}{l}0.010^{* * *} \\
(3.98)\end{array}$ & $\begin{array}{c}0.009^{* * *} \\
(3.26)\end{array}$ & $\begin{array}{l}0.000 \\
(0.24)\end{array}$ & $\begin{array}{l}0.068^{* *} \\
(4.45)\end{array}$ & $\begin{array}{l}0.012^{* *} \\
(3.43)\end{array}$ & $\begin{array}{c}0.014^{* * *} \\
(3.25)\end{array}$ & $\begin{array}{c}0.001^{* *} \\
(2.77)\end{array}$ \\
\hline France & $\begin{array}{l}0.009^{* * *} \\
(3.05)\end{array}$ & $\begin{array}{c}0.011^{* * *} \\
(3.53)\end{array}$ & $\begin{array}{l}0.003 \\
(1.84)\end{array}$ & $\begin{array}{l}0.038^{*} \\
(2.15)\end{array}$ & $\begin{array}{l}0.004 \\
(0.88)\end{array}$ & $\begin{array}{l}0.006 \\
(1.26)\end{array}$ & $\begin{array}{c}0.002^{* * *} \\
(3.03)\end{array}$ \\
\hline Denmark & $\begin{array}{l}0.005 \\
(1.72)\end{array}$ & $\begin{array}{l}0.006^{*} \\
(2.04)\end{array}$ & $\begin{array}{l}-0.002 \\
(-1.15)\end{array}$ & $\begin{array}{c}0.061^{* *} \\
(3.08)\end{array}$ & $\begin{array}{l}0.006 \\
(1.30)\end{array}$ & $\begin{array}{l}0.004 \\
(0.68)\end{array}$ & $\begin{array}{l}0.002^{*} \\
(2.30)\end{array}$ \\
\hline Greece & $\begin{array}{l}0.009^{* * *} \\
(3.32)\end{array}$ & $\begin{array}{c}0.008^{* * *} \\
(2.89)\end{array}$ & $\begin{array}{l}-0.001 \\
(-0.56)\end{array}$ & $\begin{array}{c}0.041^{* *} \\
(3.33)\end{array}$ & $\begin{array}{l}0.016^{* *} \\
(4.50)\end{array}$ & $\begin{array}{c}0.016^{* * *} \\
(3.96)\end{array}$ & $\begin{array}{l}0.001^{*} \\
(2.36)\end{array}$ \\
\hline Switzerland & $\begin{array}{l}0.009^{*} \\
(2.43)\end{array}$ & $\begin{array}{c}0.010^{* * *} \\
(2.72)\end{array}$ & $\begin{array}{l}-0.000 \\
(-0.13)\end{array}$ & $\begin{array}{l}0.053^{*} \\
(2.34)\end{array}$ & $\begin{array}{l}0.010 \\
(1.70)\end{array}$ & $\begin{array}{l}0.008 \\
(1.05)\end{array}$ & $\begin{array}{l}0.001 \\
(1.15)\end{array}$ \\
\hline Belgium & $\begin{array}{l}0.003 \\
(1.14)\end{array}$ & $\begin{array}{l}0.001 \\
(0.47)\end{array}$ & $\begin{array}{l}0.001 \\
(0.52)\end{array}$ & $\begin{array}{l}0.023 \\
(1.69)\end{array}$ & $\begin{array}{l}0.008^{*} \\
(2.24)\end{array}$ & $\begin{array}{c}0.013^{* * *} \\
(3.09)\end{array}$ & $\begin{array}{c}0.001^{* * *} \\
(3.21)\end{array}$ \\
\hline Czech Republic & $\begin{array}{l}0.004 \\
(1.48)\end{array}$ & $\begin{array}{l}0.004 \\
(1.23)\end{array}$ & $\begin{array}{c}0.006^{* * *} \\
(3.66)\end{array}$ & $\begin{array}{l}0.031 \\
(1.60)\end{array}$ & $\begin{array}{c}0.017^{* *} \\
(4.03)\end{array}$ & $\begin{array}{l}0.012^{*} \\
(2.52)\end{array}$ & $\begin{array}{c}0.002^{* * *} \\
(3.74)\end{array}$ \\
\hline Poland & $\begin{array}{l}0.010^{* * *} \\
(2.92)\end{array}$ & $\begin{array}{l}0.009^{*} \\
(2.42)\end{array}$ & $\begin{array}{l}0.003 \\
(1.17)\end{array}$ & $\begin{array}{l}0.049^{*} \\
(2.28)\end{array}$ & $\begin{array}{l}0.013^{*} \\
(2.38)\end{array}$ & $\begin{array}{c}0.022^{* * *} \\
(3.32)\end{array}$ & $\begin{array}{l}0.003^{* * *} \\
(3.07)\end{array}$ \\
\hline
\end{tabular}

Notes: $t$-statistics are reported in parentheses together with the coefficients which are estimated using OLS. Height is in $\mathrm{cm}$. Standard errors are clustered at the individual level. Regressions for each country include all the control variables listed in Table 4. SHARE waves 1-3 are used covering the years 2002-2008 for 13 European countries. 
Table 6: Coefficients on Country Dummies in Height and Cognitive Outcomes

\begin{tabular}{|c|c|c|c|c|c|c|c|c|}
\hline & $\begin{array}{c}\text { Height } \\
(\mathrm{cm}) \\
(1)\end{array}$ & $\begin{array}{c}\text { Reading } \\
\text { skill } \\
\text { (2) }\end{array}$ & $\begin{array}{c}\text { Writing } \\
\text { skill } \\
\text { (3) }\end{array}$ & $\begin{array}{c}\text { Date } \\
\text { questions } \\
\text { score } \\
\text { (4) }\end{array}$ & $\begin{array}{c}\text { Verbal } \\
\text { fluency } \\
(5)\end{array}$ & $\begin{array}{c}\text { Immediate } \\
\text { recall } \\
\text { score } \\
(6)\end{array}$ & $\begin{array}{c}\text { Delayed } \\
\text { recall } \\
\text { score } \\
(7)\end{array}$ & $\begin{array}{c}\text { Numeracy } \\
\text { test score } \\
\text { (8) }\end{array}$ \\
\hline Austria & $\begin{array}{l}5.667^{* * *} \\
(26.95)\end{array}$ & $\begin{array}{l}0.962^{* *} \\
(33.23)\end{array}$ & $\begin{array}{l}0.942^{* *} \\
(32.09)\end{array}$ & $\begin{array}{l}0.200^{* *} \\
(12.73)\end{array}$ & $\begin{array}{l}6.646^{* *} \\
(30.85)\end{array}$ & $\begin{array}{l}1.471^{* *} \\
(31.81)\end{array}$ & $\begin{array}{l}1.161^{* *} \\
(22.78)\end{array}$ & $\begin{array}{l}0.151^{* *} \\
(24.26)\end{array}$ \\
\hline Germany & $\begin{array}{l}6.460^{* * *} \\
(35.94)\end{array}$ & $\begin{array}{l}0.478^{* * *} \\
(19.45)\end{array}$ & $\begin{array}{l}0.403^{* *} \\
(16.32)\end{array}$ & $\begin{array}{l}0.167^{* * *} \\
(11.62)\end{array}$ & $\begin{array}{l}4.802^{* *} \\
(31.35)\end{array}$ & $\begin{array}{l}1.363^{* * *} \\
(35.94)\end{array}$ & $\begin{array}{l}0.882^{* *} \\
(21.72)\end{array}$ & $\begin{array}{l}0.132^{* *} \\
(24.06)\end{array}$ \\
\hline Sweden & $\begin{array}{l}7.338^{* * *} \\
(41.41)\end{array}$ & $\begin{array}{l}1.172^{* * *} \\
(48.11)\end{array}$ & $\begin{array}{l}1.132^{* * *} \\
(45.48)\end{array}$ & $\begin{array}{l}0.193^{* *} \\
(13.61)\end{array}$ & $\begin{array}{l}7.214^{* 3} \\
(47.19)\end{array}$ & $\begin{array}{l}1.280^{* * *} \\
(35.58)\end{array}$ & $\begin{array}{l}1.234^{* * *} \\
(31.57)\end{array}$ & $\begin{array}{l}0.140^{* *} \\
(26.21)\end{array}$ \\
\hline Netherlands & $\begin{array}{l}8.191^{* * *} \\
(44.81)\end{array}$ & $\begin{array}{l}0.385^{* * *} \\
(15.27)\end{array}$ & $\begin{array}{l}0.283^{* *} \\
(11.12)\end{array}$ & $\begin{array}{c}0.124^{* * *} \\
(8.51)\end{array}$ & $\begin{array}{l}3.600^{* *} \\
(25.32)\end{array}$ & $\begin{array}{l}1.168^{* * *} \\
(31.45)\end{array}$ & $\begin{array}{l}1.039^{* * *} \\
(25.43)\end{array}$ & $\begin{array}{l}0.136^{* *} \\
(24.71)\end{array}$ \\
\hline Italy & $\begin{array}{l}2.132^{\text {*** }} \\
(12.31)\end{array}$ & $\begin{array}{l}0.308^{* * *} \\
(12.49)\end{array}$ & $\begin{array}{l}0.270^{* *} \\
(11.10)\end{array}$ & $\begin{array}{c}0.1366^{* * *} \\
(9.08)\end{array}$ & $\begin{array}{l}-0.027 \\
(-0.20)\end{array}$ & $\begin{array}{l}0.543^{* * *} \\
(15.84)\end{array}$ & $\begin{array}{c}0.309^{* * *} \\
(8.29)\end{array}$ & $\begin{array}{c}0.046^{* *} \\
(8.61)\end{array}$ \\
\hline France & $\begin{array}{l}2.947^{* * *} \\
(16.69)\end{array}$ & $\begin{array}{l}0.751^{* * *} \\
(28.84)\end{array}$ & $\begin{array}{l}0.619^{* *} \\
(23.42)\end{array}$ & $\begin{array}{l}0.156^{* *} \\
(10.52)\end{array}$ & $\begin{array}{l}4.221^{* * *} \\
(26.73)\end{array}$ & $\begin{array}{l}0.639^{* * *} \\
(17.28)\end{array}$ & $\begin{array}{l}0.421^{* * *} \\
(10.87)\end{array}$ & $\begin{array}{l}0.081^{* *} \\
(14.44)\end{array}$ \\
\hline Denmark & $\begin{array}{l}7.080^{* * * *} \\
(38.37)\end{array}$ & $\begin{array}{l}0.618^{* * *} \\
(23.21)\end{array}$ & $\begin{array}{l}0.544^{* *} \\
(19.81)\end{array}$ & $\begin{array}{c}0.107^{* *} \\
(6.83)\end{array}$ & $\begin{array}{l}4.636^{* *} \\
(28.68)\end{array}$ & $\begin{array}{l}1.157^{* *} \\
(28.97)\end{array}$ & $\begin{array}{l}1.136^{* * *} \\
(26.18)\end{array}$ & $\begin{array}{l}0.090^{* *} \\
(15.35)\end{array}$ \\
\hline Greece & $\begin{array}{l}3.728^{* * *} \\
(21.16)\end{array}$ & $\begin{array}{l}0.423^{* *} \\
(16.66)\end{array}$ & $\begin{array}{l}0.384^{* *} \\
(15.22)\end{array}$ & $\begin{array}{l}0.224^{* * *} \\
(15.94)\end{array}$ & $\begin{array}{c}-0.396^{* *} \\
(-3.03)\end{array}$ & $\begin{array}{l}0.969^{* *} \\
(28.22)\end{array}$ & $\begin{array}{l}0.683^{* *} \\
(18.35)\end{array}$ & $\begin{array}{l}0.130^{* * *} \\
(23.77)\end{array}$ \\
\hline Switzerland & $\begin{array}{l}4.704^{* * *} \\
(21.09)\end{array}$ & $\begin{array}{l}0.884^{* * *} \\
(29.16)\end{array}$ & $\begin{array}{l}0.763^{* *} \\
(24.40)\end{array}$ & $\begin{array}{l}0.214^{* *} \\
(12.91)\end{array}$ & $\begin{array}{l}4.608^{* * *} \\
(25.43)\end{array}$ & $\begin{array}{l}1.278^{* * *} \\
(27.12)\end{array}$ & $\begin{array}{l}1.138^{* *} \\
(21.13)\end{array}$ & $\begin{array}{l}0.154^{* *} \\
(23.85)\end{array}$ \\
\hline Belgium & $\begin{array}{l}4.351^{\text {*** }} \\
(24.81)\end{array}$ & $\begin{array}{l}0.632^{* * *} \\
(25.10)\end{array}$ & $\begin{array}{l}0.471^{* * *} \\
(18.38)\end{array}$ & $\begin{array}{c}0.101^{* * *} \\
(7.06)\end{array}$ & $\begin{array}{l}3.421^{* * *} \\
(24.39)\end{array}$ & $\begin{array}{l}0.811^{* * *} \\
(22.66)\end{array}$ & $\begin{array}{l}0.453^{* *} \\
(11.63)\end{array}$ & $\begin{array}{l}0.056^{* *} \\
(10.74)\end{array}$ \\
\hline Czech Republic & $\begin{array}{l}5.364^{* * *} \\
(28.10)\end{array}$ & $\begin{array}{l}0.523^{* *} \\
(18.34)\end{array}$ & $\begin{array}{l}0.461^{* * *} \\
(16.08)\end{array}$ & $\begin{array}{c}0.073^{* * *} \\
(4.38)\end{array}$ & $\begin{array}{l}1.963^{* * *} \\
(11.12)\end{array}$ & $\begin{array}{l}0.654^{* *} \\
(15.89)\end{array}$ & $\begin{array}{l}0.086 \\
(1.91)\end{array}$ & $\begin{array}{l}0.081^{* *} \\
(13.20)\end{array}$ \\
\hline Poland & $\begin{array}{l}3.140^{* * * 3} \\
(16.99)\end{array}$ & $\begin{array}{c}0.272^{* * *} \\
(9.43)\end{array}$ & $\begin{array}{c}0.250^{* *} \\
(8.70)\end{array}$ & $\begin{array}{c}0.107^{* * *} \\
(5.99)\end{array}$ & $\begin{array}{l}-0.076 \\
(-0.46)\end{array}$ & $\begin{array}{c}0.295^{* *} \\
(6.97)\end{array}$ & $\begin{array}{l}-0.012 \\
(-0.27)\end{array}$ & $\begin{array}{c}0.035^{* *} \\
(5.27)\end{array}$ \\
\hline
\end{tabular}

Notes: Spain is the omitted country in these regressions. $t$-statistics are reported in parentheses together with the coefficients which are estimated using OLS.

Table 7: Cross-Country Correlations between Height and Cognitive Outcomes

\begin{tabular}{|c|c|c|c|c|c|c|c|}
\hline & $\begin{array}{c}\begin{array}{c}\text { Reading } \\
\text { skill }\end{array} \\
(1) \\
\end{array}$ & $\begin{array}{c}\text { Writing } \\
\text { skill } \\
(2) \\
\end{array}$ & $\begin{array}{c}\text { Date } \\
\text { questions } \\
\text { score } \\
(3)\end{array}$ & $\begin{array}{c}\text { Verbal } \\
\text { fluency } \\
(4) \\
\end{array}$ & $\begin{array}{c}\text { Immediate } \\
\text { recall } \\
\text { score } \\
(5) \\
\end{array}$ & $\begin{array}{c}\text { Delayed } \\
\text { recall } \\
\text { score } \\
(6) \\
\end{array}$ & $\begin{array}{c}\text { Numeracy } \\
\text { test score } \\
(7)\end{array}$ \\
\hline Pearson's correlation & 0.334 & 0.331 & -0.015 & 0.650 & 0.722 & 0.703 & 0.605 \\
\hline Spearman's rank & 0.315 & 0.350 & 0.035 & 0.650 & 0.741 & 0.692 & 0.641 \\
\hline Kendall's rank & 0.242 & 0.273 & -0.045 & 0.455 & 0.515 & 0.515 & 0.439 \\
\hline
\end{tabular}

Notes: Each row presents the correlation between the country dummies in height (column 1 in Table 6) and the country dummies for each respective cognitive outcome in Table 6.

Table 8: Cross-Regional Correlations between Height and Cognitive Outcomes

\begin{tabular}{|c|c|c|c|c|c|c|c|}
\hline & $\begin{array}{c}\begin{array}{c}\text { Reading } \\
\text { skill }\end{array} \\
(1) \\
\end{array}$ & $\begin{array}{c}\begin{array}{c}\text { Writing } \\
\text { skill }\end{array} \\
(2)\end{array}$ & $\begin{array}{c}\text { Date } \\
\text { questions } \\
\text { score } \\
\text { (3) } \\
\end{array}$ & $\begin{array}{c}\text { Verbal } \\
\text { fluency } \\
(4) \\
\end{array}$ & $\begin{array}{c}\text { Immediate } \\
\text { recall } \\
\text { score } \\
(5) \\
\end{array}$ & $\begin{array}{c}\text { Delayed } \\
\text { recall } \\
\text { score } \\
(6) \\
\end{array}$ & $\begin{array}{c}\text { Numeracy } \\
\text { test score } \\
(7)\end{array}$ \\
\hline Pearson's correlation & 0.478 & 0.452 & 0.243 & 0.504 & 0.651 & 0.524 & 0.539 \\
\hline Spearman's rank & 0.472 & 0.462 & 0.177 & 0.615 & 0.672 & 0.545 & 0.581 \\
\hline Kendall's rank & 0.337 & 0.324 & 0.119 & 0.427 & 0.486 & 0.385 & 0.393 \\
\hline
\end{tabular}

Notes: Each row presents the correlation between the regional dummies in height and the regional dummies for each respective cognitive outcome. 
Table 9: IV-LATE Analysis

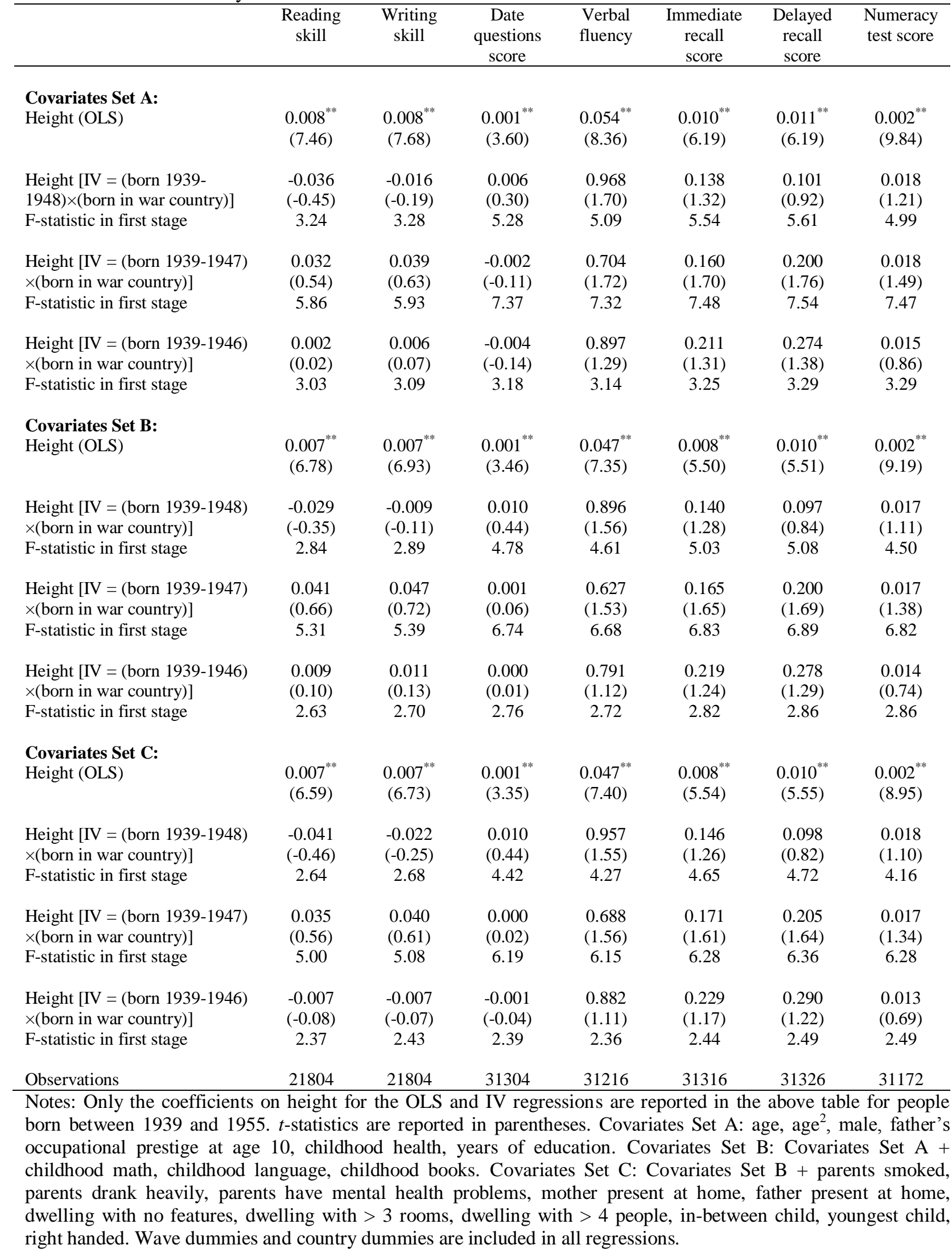


Table 10: Country Specific IV-LATE Analysis for Extreme Famine hit Countries

\begin{tabular}{|c|c|c|c|c|c|c|c|}
\hline & $\begin{array}{l}\text { Reading } \\
\text { skill }\end{array}$ & $\begin{array}{l}\text { Writing } \\
\text { skill }\end{array}$ & $\begin{array}{l}\text { Date } \\
\text { questions } \\
\text { score } \\
\end{array}$ & $\begin{array}{l}\text { Verbal } \\
\text { fluency }\end{array}$ & $\begin{array}{l}\text { Immediate } \\
\text { recall } \\
\text { score }\end{array}$ & $\begin{array}{c}\text { Delayed } \\
\text { recall } \\
\text { score }\end{array}$ & $\begin{array}{l}\text { Numeracy } \\
\text { test score }\end{array}$ \\
\hline $\begin{array}{l}\text { Greece } \\
\text { Height (OLS) }\end{array}$ & $\begin{array}{c}0.010^{* *} \\
(5.74)\end{array}$ & $\begin{array}{c}0.010^{* *} \\
(5.60)\end{array}$ & $\begin{array}{l}0.001 \\
(1.10)\end{array}$ & $\begin{array}{l}0.052^{* *} \\
(4.74)\end{array}$ & $\begin{array}{c}0.011^{* *} \\
(4.26)\end{array}$ & $\begin{array}{c}0.010^{* *} \\
(3.22)\end{array}$ & $\begin{array}{c}0.002^{* * *} \\
(4.83)\end{array}$ \\
\hline $\begin{array}{l}\text { Height [IV = (born 1939-1948) } \\
\times(\text { born in Greece)] } \\
\text { F-statistic in first stage }\end{array}$ & $\begin{array}{c}0.106 \\
(1.80) \\
8.33\end{array}$ & $\begin{array}{c}0.138^{*} \\
(2.06) \\
8.34\end{array}$ & $\begin{array}{c}-0.009 \\
(-0.70) \\
10.88\end{array}$ & $\begin{array}{l}0.086 \\
(0.36) \\
10.63\end{array}$ & $\begin{array}{l}0.135 \\
(1.93) \\
10.77\end{array}$ & $\begin{array}{c}-0.029 \\
(-0.39) \\
10.79\end{array}$ & $\begin{array}{l}0.013 \\
(1.38) \\
10.55\end{array}$ \\
\hline $\begin{array}{l}\text { Height [IV = (born 1939-1947) } \\
\times(\text { born in Greece)] } \\
\text { F-statistic in first stage }\end{array}$ & $\begin{array}{l}0.080^{*} \\
(2.07) \\
17.12\end{array}$ & $\begin{array}{l}0.085^{*} \\
(2.12) \\
17.13\end{array}$ & $\begin{array}{c}-0.013 \\
(-1.33) \\
18.26\end{array}$ & $\begin{array}{c}-0.003 \\
(-0.02) \\
18.30\end{array}$ & $\begin{array}{l}0.123^{*} \\
(2.37) \\
18.37\end{array}$ & $\begin{array}{l}0.035 \\
(0.62) \\
18.40\end{array}$ & $\begin{array}{l}0.011 \\
(1.60) \\
18.72\end{array}$ \\
\hline $\begin{array}{l}\text { Height }[\mathrm{IV}=(\text { born } 1939-1946) \\
\times(\text { born in Greece }) \\
\text { F-statistic in first stage }\end{array}$ & $\begin{array}{c}0.089 \\
(1.68) \\
9.92\end{array}$ & $\begin{array}{c}0.101 \\
(1.80) \\
9.93\end{array}$ & $\begin{array}{c}-0.017 \\
(-1.14) \\
9.40\end{array}$ & $\begin{array}{c}-0.190 \\
(-0.72) \\
9.38\end{array}$ & $\begin{array}{c}0.143 \\
(1.88) \\
9.46\end{array}$ & $\begin{array}{c}0.023 \\
(0.29) \\
9.48\end{array}$ & $\begin{array}{c}0.009 \\
(0.92) \\
9.73\end{array}$ \\
\hline Observations & 6405 & 6406 & 9694 & 9676 & 9690 & 9691 & 9666 \\
\hline $\begin{array}{l}\text { Netherlands } \\
\text { Height (OLS) }\end{array}$ & $\begin{array}{c}0.008^{* *} \\
(4.53)\end{array}$ & $\begin{array}{c}0.007^{* *} \\
(4.01)\end{array}$ & $\begin{array}{l}0.001 \\
(1.82)\end{array}$ & $\begin{array}{l}0.054^{* *} \\
(4.87)\end{array}$ & $\begin{array}{l}0.006^{*} \\
(2.27)\end{array}$ & $\begin{array}{l}0.006 \\
(1.78)\end{array}$ & $\begin{array}{c}0.002^{* * *} \\
(5.62)\end{array}$ \\
\hline $\begin{array}{l}\text { Height }[\text { IV }=(\text { born } 1939-1948) \\
\times(\text { born in the Netherlands)] } \\
\text { F-statistic in first stage }\end{array}$ & $\begin{array}{c}-0.094 \\
(-1.34) \\
5.87\end{array}$ & $\begin{array}{c}-0.087 \\
(-1.27) \\
6.20\end{array}$ & $\begin{array}{c}0.029 \\
(1.49) \\
7.34\end{array}$ & $\begin{array}{c}0.661 \\
(1.76) \\
7.32\end{array}$ & $\begin{array}{c}-0.053 \\
(-0.67) \\
7.18\end{array}$ & $\begin{array}{c}-0.020 \\
(-0.22) \\
7.34\end{array}$ & $\begin{array}{c}0.008 \\
(0.78) \\
7.35\end{array}$ \\
\hline $\begin{array}{l}\text { Height }[\text { IV }=(\text { born } 1939-1947) \\
\times(\text { born in the Netherlands })] \\
\text { F-statistic in first stage }\end{array}$ & $\begin{array}{c}-0.030 \\
(-0.54) \\
6.64\end{array}$ & $\begin{array}{c}-0.043 \\
(-0.75) \\
7.04\end{array}$ & $\begin{array}{c}0.012 \\
(0.74) \\
8.63\end{array}$ & $\begin{array}{c}0.634 \\
(1.87) \\
8.62\end{array}$ & $\begin{array}{c}-0.008 \\
(-0.12) \\
8.37\end{array}$ & $\begin{array}{c}0.020 \\
(0.24) \\
8.56\end{array}$ & $\begin{array}{c}0.017 \\
(1.54) \\
8.76\end{array}$ \\
\hline $\begin{array}{l}\text { Height }[\text { IV }=(\text { born } 1939-1946) \\
\times(\text { born in the Netherlands })] \\
\text { F-statistic in first stage }\end{array}$ & $\begin{array}{c}-0.035 \\
(-0.46) \\
3.60\end{array}$ & $\begin{array}{c}-0.060 \\
(-0.75) \\
3.95\end{array}$ & $\begin{array}{c}0.007 \\
(0.38) \\
6.25\end{array}$ & $\begin{array}{c}0.824 \\
(1.85) \\
6.20\end{array}$ & $\begin{array}{c}-0.011 \\
(-0.13) \\
5.94\end{array}$ & $\begin{array}{c}0.037 \\
(0.38) \\
6.13\end{array}$ & $\begin{array}{c}0.014 \\
(1.14) \\
6.32\end{array}$ \\
\hline Observations & 6534 & 6537 & 9574 & 9551 & 9574 & 9576 & 9546 \\
\hline
\end{tabular}

Notes: Only the coefficients on height for the OLS and IV regressions are reported in the above table for people born between 1939 and 1955. $t$-statistics are reported in parentheses. Non-war countries: Spain, Switzerland, Sweden. Covariate set $\mathrm{C}$ is used in all models (see notes to Table 9 for the detailed list of covariates). Wave dummies and country dummies are included in all regressions. 
Figure 1: Average Height by Country: 13 European Nations

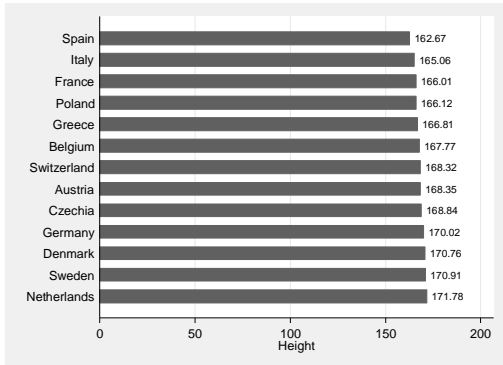

(a) Full sample

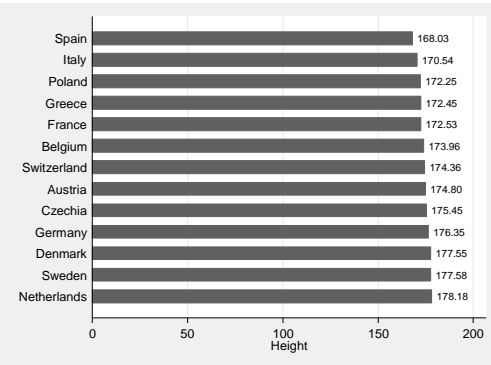

(b) Men

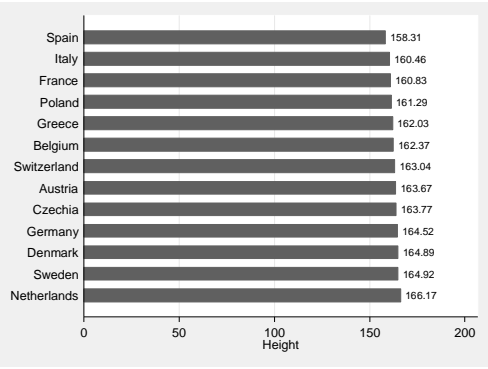

(c) Women

Figure 2: Average Dates Scores by Country: 13 European Nations

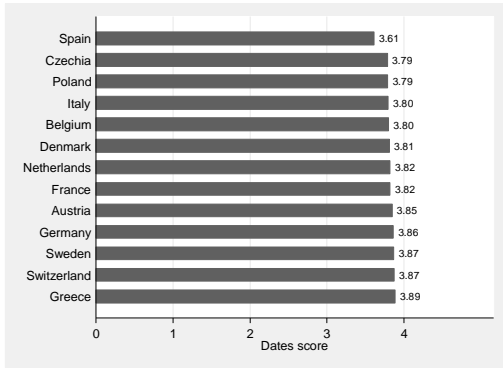

(a) Full sample

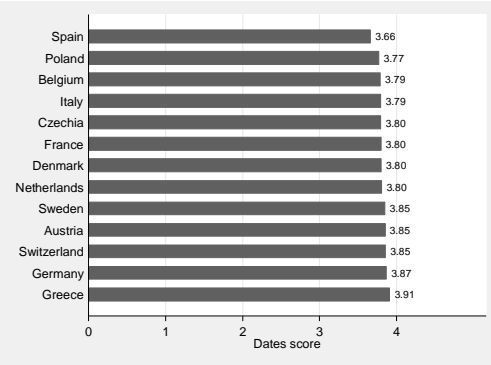

(b) Men

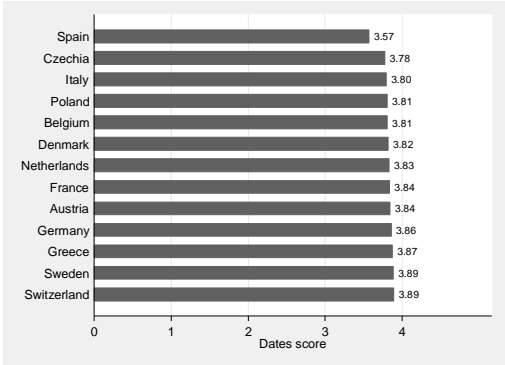

(c) Women

Figure 3: Average Numeracy Scores by Country: 13 European Nations

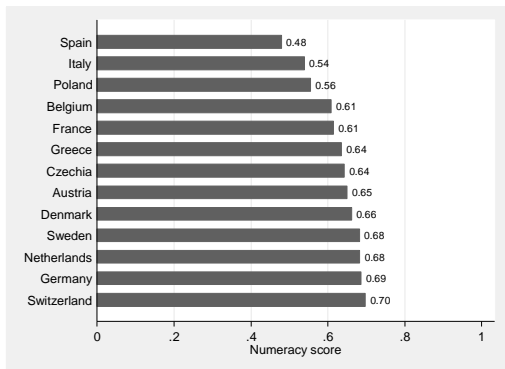

(a) Full sample

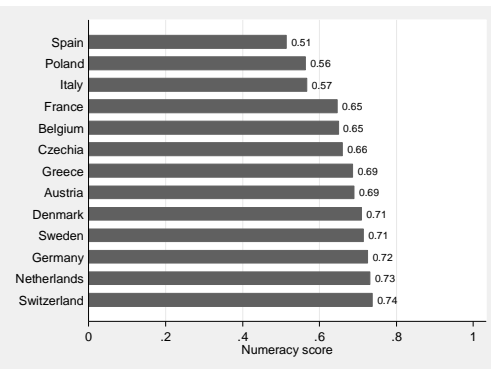

(b) Men

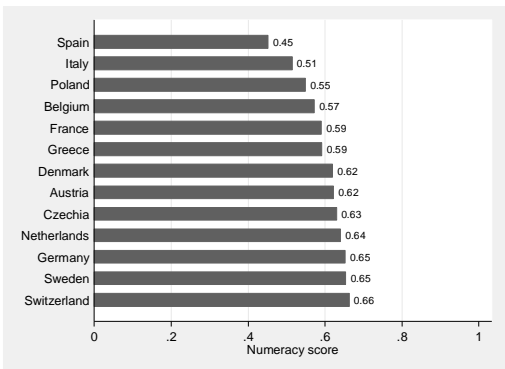

(c) Women

Figure 4: Average Verbal Fluency Scores by Country: 13 European Nations

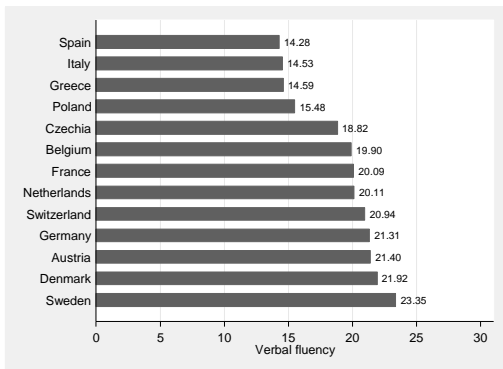

(a) Full sample

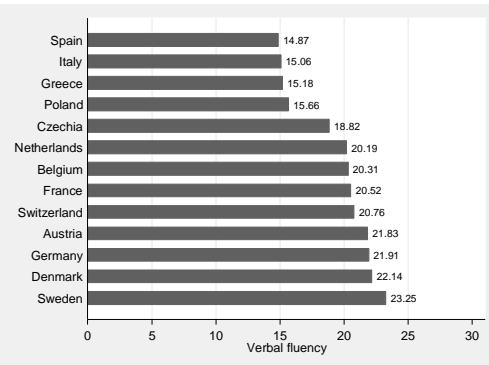

(b) Men

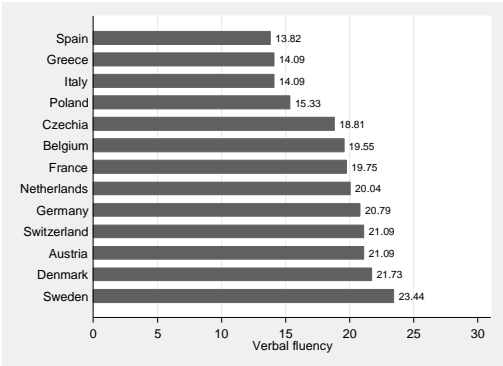

(c) Women 
Figure 5: Average Immediate Recall Scores by Country: 13 European Nations

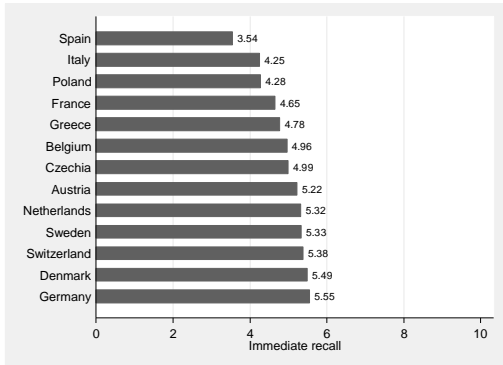

(a) Full sample

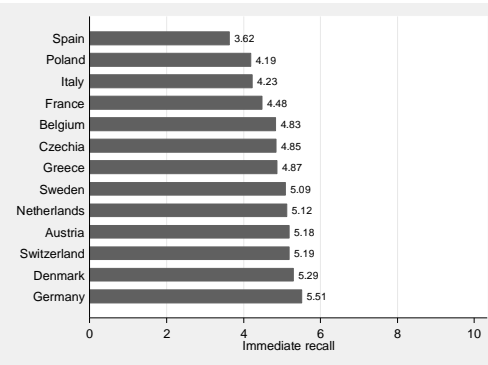

(b) Men

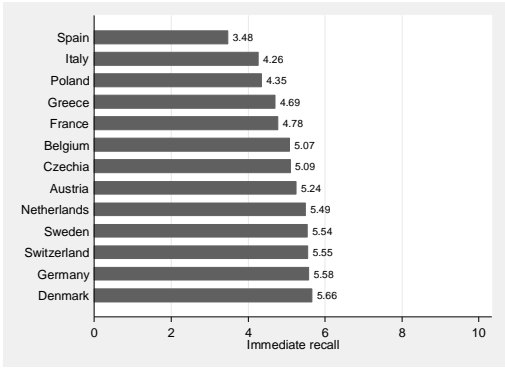

(c) Women

Figure 6: Average Delayed Recall Scores by Country: 13 European Nations

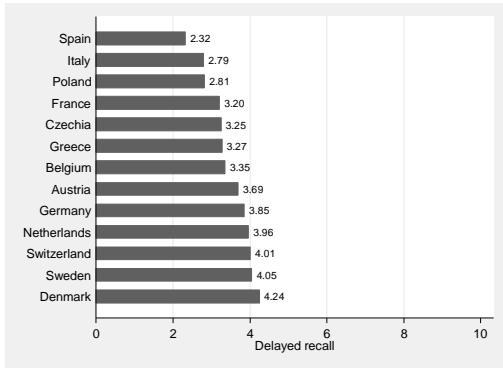

(a) Full sample

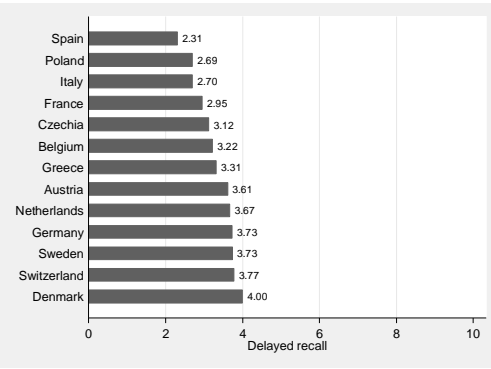

(b) Men

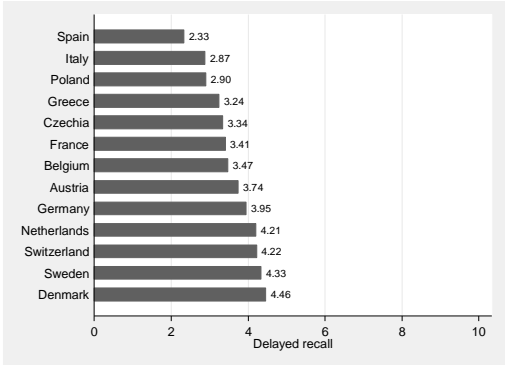

(c) Women

Figure 7: Average Reading Skill Scores by Country: 13 European Nations

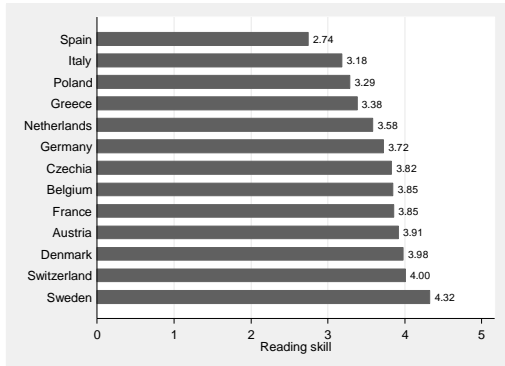

(a) Full sample

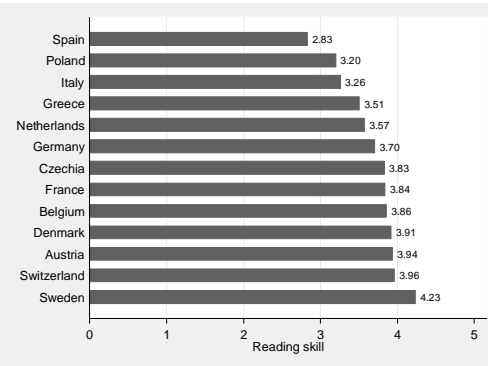

(b) Men

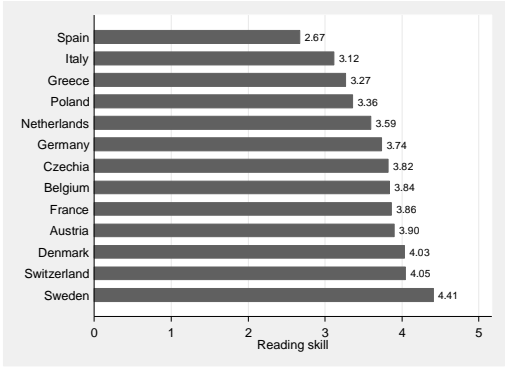

(c) Women

Figure 8: Average Writing Skill Scores by Country: 13 European Nations

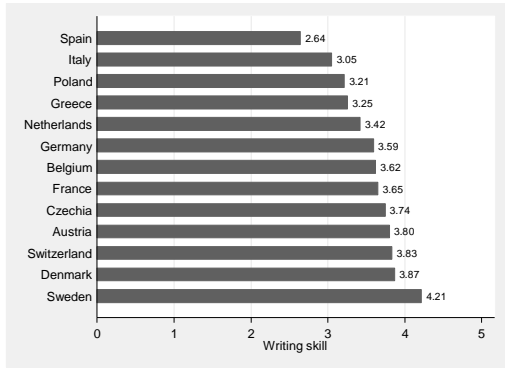

(a) Full sample

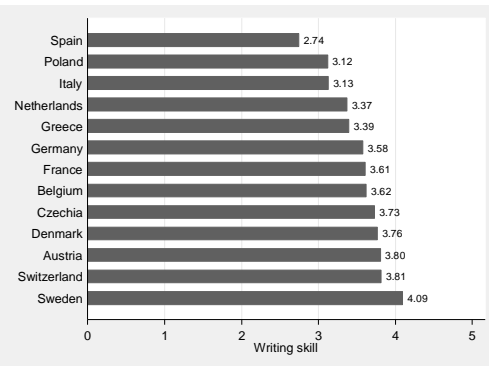

(b) Men

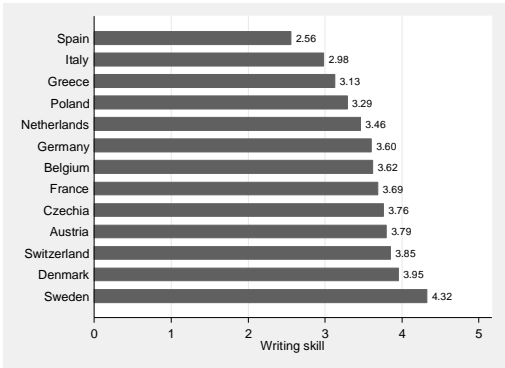

(c) Women 
Figure 9: Positive Correlation between Height and Cognitive Functioning: 13 European Nations

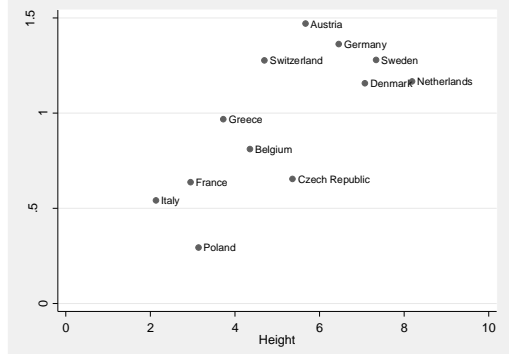

(a) Height and immediate recall

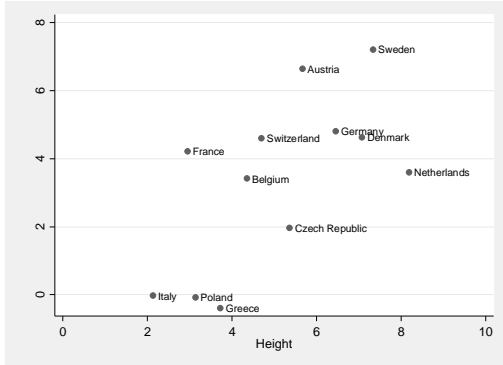

(c) Height and verbal fluency

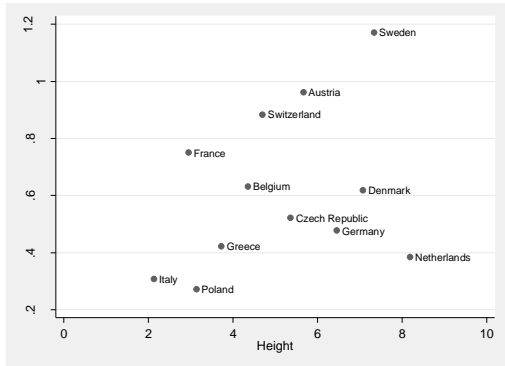

(e) Height and reading skills

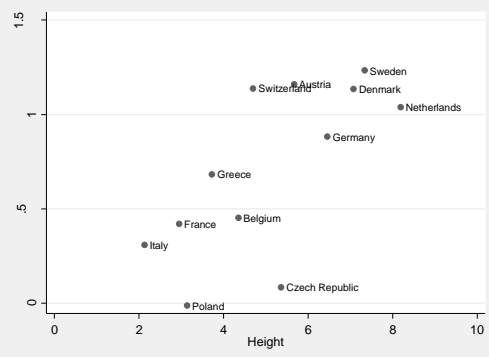

(b) Height and delayed recall

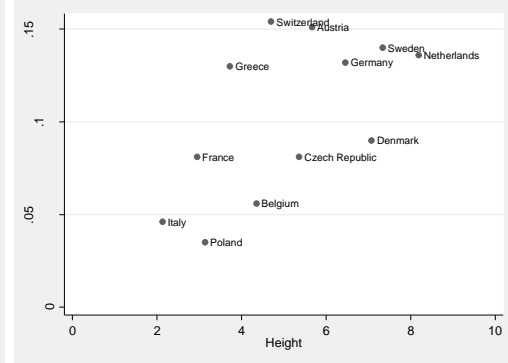

(d) Height and numeracy

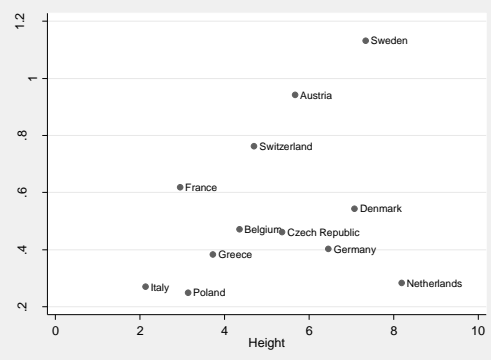

(f) Height and writing skills

Figure 10: Height Trends by Birth Cohort for War and Non-War European Countries
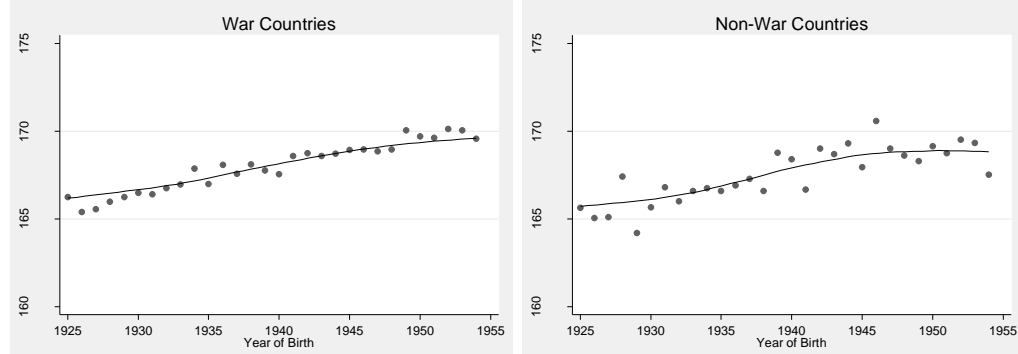

Figure 11: Education Trends by Birth Cohort for War and Non-War European Countries
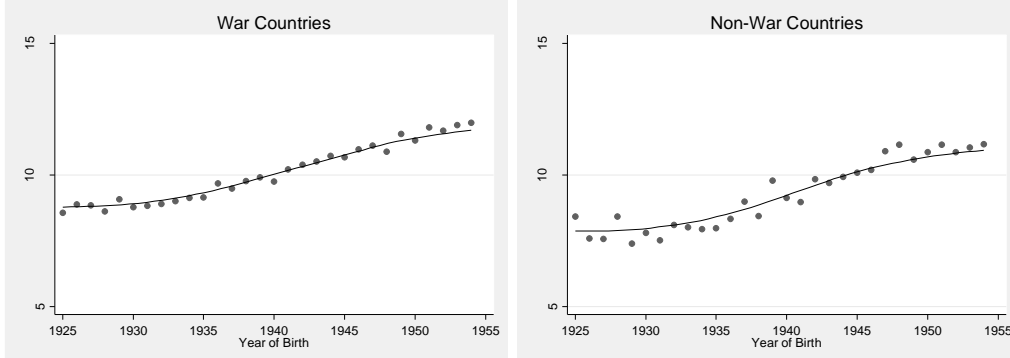


\section{APPENDIX}

Table A.1: Determinants of Height, Education and Occupational Choice using SHARE

\begin{tabular}{|c|c|c|c|c|}
\hline & Height $(\mathrm{cm})$ & Years of Schooling & White Collar Job & White Collar Job \\
\hline Height $(\mathrm{cm})$ & & $\begin{array}{l}0.041^{* *} \\
(14.27)\end{array}$ & $\begin{array}{l}0.003^{* *} \\
(6.37)\end{array}$ & $\begin{array}{l}0.002^{* * *} \\
(3.91)\end{array}$ \\
\hline Years of schooling & & & & $\begin{array}{l}0.035^{* * *} \\
(33.42)\end{array}$ \\
\hline Father white collar job & $\begin{array}{l}0.612^{* *} \\
(5.55)\end{array}$ & $\begin{array}{l}0.985^{* *} \\
(16.24)\end{array}$ & $\begin{array}{l}0.176^{* *} \\
(20.52)\end{array}$ & $\begin{array}{l}0.142^{* * * *} \\
(16.76)\end{array}$ \\
\hline Childhood health & $\begin{array}{l}0.082 \\
(1.81)\end{array}$ & $\begin{array}{l}0.037 \\
(1.56)\end{array}$ & $\begin{array}{l}-0.001 \\
(-0.35)\end{array}$ & $\begin{array}{l}-0.002 \\
(-0.53)\end{array}$ \\
\hline Age & $\begin{array}{c}-0.151^{* *} \\
(-3.55)\end{array}$ & $\begin{array}{l}-0.245^{* *} \\
(-11.47)\end{array}$ & $\begin{array}{l}-0.002 \\
(-0.41)\end{array}$ & $\begin{array}{l}0.003 \\
(0.67)\end{array}$ \\
\hline $\mathrm{Age}^{2} / 100$ & $\begin{array}{l}0.013 \\
(0.40)\end{array}$ & $\begin{array}{l}0.120^{* *} \\
(7.61)\end{array}$ & $\begin{array}{l}-0.001 \\
(-0.25)\end{array}$ & $\begin{array}{l}-0.002 \\
(-0.73)\end{array}$ \\
\hline Male & $\begin{array}{l}11.335^{* * *} \\
(162.52)\end{array}$ & $\begin{array}{l}0.354^{* * *} \\
(7.32)\end{array}$ & $\begin{array}{l}-0.123^{* *} \\
(-13.66)\end{array}$ & $\begin{array}{l}-0.137^{* * *} \\
(-15.66)\end{array}$ \\
\hline Childhood math ability & $\begin{array}{l}0.183^{* *} \\
(3.27)\end{array}$ & $\begin{array}{l}0.492^{* *} \\
(16.69)\end{array}$ & $\begin{array}{l}0.049^{* *} \\
(11.24)\end{array}$ & $\begin{array}{l}0.031^{* * *} \\
(7.39)\end{array}$ \\
\hline Childhood language ability & $\begin{array}{l}0.085 \\
(1.46)\end{array}$ & $\begin{array}{l}0.561^{* * *} \\
(18.13)\end{array}$ & $\begin{array}{l}0.063^{* *} \\
(13.83)\end{array}$ & $\begin{array}{l}0.044^{* * *} \\
(9.78)\end{array}$ \\
\hline Childhood books at home & $\begin{array}{l}0.367^{* * *} \\
(8.39)\end{array}$ & $\begin{array}{l}0.696^{* * *} \\
(28.86)\end{array}$ & $\begin{array}{l}0.058^{* * *} \\
(16.63)\end{array}$ & $\begin{array}{l}0.033^{* * *} \\
(9.37)\end{array}$ \\
\hline Parents smoked & $\begin{array}{l}-0.021 \\
(-0.22)\end{array}$ & $\begin{array}{l}-0.103^{*} \\
(-2.12)\end{array}$ & $\begin{array}{l}-0.014 \\
(-1.92)\end{array}$ & $\begin{array}{l}-0.012 \\
(-1.69)\end{array}$ \\
\hline Parents drank heavily & $\begin{array}{c}-0.455^{* * *} \\
(-2.77)\end{array}$ & $\begin{array}{c}-0.379^{* * *} \\
(-4.96)\end{array}$ & $\begin{array}{c}-0.051^{* *} \\
(-4.07)\end{array}$ & $\begin{array}{c}-0.035^{* * *} \\
(-2.89)\end{array}$ \\
\hline Parents have mental health problems & $\begin{array}{l}-0.736^{*} \\
(-2.45)\end{array}$ & $\begin{array}{l}0.133 \\
(0.89)\end{array}$ & $\begin{array}{l}-0.001 \\
(-0.05)\end{array}$ & $\begin{array}{l}-0.005 \\
(-0.23)\end{array}$ \\
\hline Mother present at home & $\begin{array}{l}0.342 \\
(1.37)\end{array}$ & $\begin{array}{l}0.119 \\
(0.92)\end{array}$ & $\begin{array}{l}0.012 \\
(0.62)\end{array}$ & $\begin{array}{l}0.006 \\
(0.32)\end{array}$ \\
\hline Father present at home & $\begin{array}{l}0.334 \\
(1.89)\end{array}$ & $\begin{array}{l}0.165 \\
(1.87)\end{array}$ & $\begin{array}{l}0.017 \\
(1.26)\end{array}$ & $\begin{array}{l}0.011 \\
(0.83)\end{array}$ \\
\hline Dwelling with no features & $\begin{array}{l}-0.209 \\
(-1.88)\end{array}$ & $\begin{array}{c}-0.493^{* * *} \\
(-9.02)\end{array}$ & $\begin{array}{l}-0.107^{* * *} \\
(-11.50)\end{array}$ & $\begin{array}{c}-0.087^{* * *} \\
(-9.64)\end{array}$ \\
\hline Dwelling with $>3$ rooms & $\begin{array}{l}0.250^{*} \\
(2.50)\end{array}$ & $\begin{array}{l}0.317^{* * *} \\
(6.14)\end{array}$ & $\begin{array}{l}0.014 \\
(1.74)\end{array}$ & $\begin{array}{l}0.003 \\
(0.37)\end{array}$ \\
\hline Dwelling with $>4$ people & $\begin{array}{c}-0.327^{* * *} \\
(-3.27)\end{array}$ & $\begin{array}{c}-0.219^{* * *} \\
(-4.22)\end{array}$ & $\begin{array}{c}-0.034^{* * *} \\
(-4.18)\end{array}$ & $\begin{array}{c}-0.026^{* * *} \\
(-3.20)\end{array}$ \\
\hline In-between child & $\begin{array}{l}-0.134 \\
(-1.46)\end{array}$ & $\begin{array}{c}-0.188^{* *} \\
(-3.88)\end{array}$ & $\begin{array}{l}-0.011 \\
(-1.21)\end{array}$ & $\begin{array}{l}-0.003 \\
(-0.37)\end{array}$ \\
\hline Youngest child & $\begin{array}{c}-0.396^{* * *} \\
(-4.45)\end{array}$ & $\begin{array}{l}-0.541^{* *} \\
(-11.61)\end{array}$ & $\begin{array}{c}-0.033^{* * *} \\
(-3.86)\end{array}$ & $\begin{array}{l}-0.018^{*} \\
(-2.21)\end{array}$ \\
\hline Right handed & $\begin{array}{l}0.217 \\
(1.63)\end{array}$ & $\begin{array}{c}0.235^{* *} \\
(3.52)\end{array}$ & $\begin{array}{l}0.008 \\
(0.65)\end{array}$ & $\begin{array}{l}0.001 \\
(0.07)\end{array}$ \\
\hline $\begin{array}{l}\text { Observations } \\
\text { R-squared }\end{array}$ & $\begin{array}{c}54705 \\
0.511\end{array}$ & $\begin{array}{c}53265 \\
0.369\end{array}$ & $\begin{array}{c}28840 \\
0.249\end{array}$ & $\begin{array}{c}28840 \\
0.299\end{array}$ \\
\hline
\end{tabular}

Notes: $t$-statistics are reported in parentheses together with the coefficients which are estimated using OLS only for natives. Height is in $\mathrm{cm}$. Standard errors are clustered at the individual level. SHARE waves 1-3 are used covering the years 2002-2008 for 13 European countries. Wave dummies and country dummies are included in all regressions. 
Table A.2: Pooled Country Regressions on Cognitive Outcomes: Subsample Analysis and Robustness Checks

Coefficient on Height

\begin{tabular}{|c|c|c|c|c|c|c|c|}
\hline & $\begin{array}{c}\text { Reading } \\
\text { skill }\end{array}$ & $\begin{array}{c}\text { Writing } \\
\text { Skill }\end{array}$ & $\begin{array}{c}\text { Date } \\
\text { questions } \\
\text { score }\end{array}$ & $\begin{array}{l}\text { Verbal } \\
\text { fluency }\end{array}$ & $\begin{array}{c}\text { Immediate } \\
\text { recall } \\
\text { score }\end{array}$ & $\begin{array}{c}\text { Delayed } \\
\text { recall } \\
\text { score }\end{array}$ & $\begin{array}{l}\text { Numeracy } \\
\text { test score }\end{array}$ \\
\hline Full sample (+ immigrants) & $\begin{array}{c}0.008^{\text {*** }} \\
(9.50)\end{array}$ & $\begin{array}{c}0.007^{* * *} \\
(8.77)\end{array}$ & $\begin{array}{l}0.001^{* *} \\
(2.60)\end{array}$ & $\begin{array}{c}0.041^{* *} \\
(8.60)\end{array}$ & $\begin{array}{c}0.008^{* * *} \\
(6.93)\end{array}$ & $\begin{array}{c}0.010^{* *} \\
(7.40)\end{array}$ & $\begin{array}{l}0.002^{* *} \\
(10.96)\end{array}$ \\
\hline Male sample & $\begin{array}{c}0.009^{* * *} \\
(7.83)\end{array}$ & $\begin{array}{c}0.009^{\text {*** }} \\
(7.34)\end{array}$ & $\begin{array}{c}0.001^{* *} \\
(2.58)\end{array}$ & $\begin{array}{c}0.055^{* *} \\
(7.79)\end{array}$ & $\begin{array}{c}0.011^{\text {*** }} \\
(6.90)\end{array}$ & $\begin{array}{c}0.013^{* *} \\
(6.64)\end{array}$ & $\begin{array}{c}0.002^{* * *} \\
(8.82)\end{array}$ \\
\hline Female sample & $\begin{array}{c}0.007^{* *} \\
(6.62)\end{array}$ & $\begin{array}{c}0.007^{\text {*** }} \\
(6.45)\end{array}$ & $\begin{array}{l}0.001 \\
(1.67)\end{array}$ & $\begin{array}{c}0.034^{* * *} \\
(5.17)\end{array}$ & $\begin{array}{c}0.007^{* *} \\
(4.38)\end{array}$ & $\begin{array}{c}0.010^{* * *} \\
(5.28)\end{array}$ & $\begin{array}{c}0.001^{* * *} \\
(6.35)\end{array}$ \\
\hline Aged 50-80 sample & $\begin{array}{c}0.007^{* * *} \\
(8.14)\end{array}$ & $\begin{array}{c}0.007^{* *} \\
(7.82)\end{array}$ & $\begin{array}{l}0.001^{*} \\
(2.48)\end{array}$ & $\begin{array}{c}0.040^{* *} \\
(7.87)\end{array}$ & $\begin{array}{c}0.008^{* * *} \\
(6.19)\end{array}$ & $\begin{array}{c}0.010^{* *} \\
(7.14)\end{array}$ & $\begin{array}{l}0.002^{* * *} \\
(11.11)\end{array}$ \\
\hline Aged $>80$ sample & $\begin{array}{c}0.017^{* *} \\
(5.44)\end{array}$ & $\begin{array}{c}0.012^{* * *} \\
(4.14)\end{array}$ & $\begin{array}{l}0.002 \\
(0.90)\end{array}$ & $\begin{array}{c}0.051^{* * *} \\
(3.79)\end{array}$ & $\begin{array}{c}0.013^{\text {*** }} \\
(3.40)\end{array}$ & $\begin{array}{l}0.008^{*} \\
(2.13)\end{array}$ & $\begin{array}{l}0.001 \\
(1.48)\end{array}$ \\
\hline Immigrant sample & $\begin{array}{c}0.013^{* * *} \\
(4.52)\end{array}$ & $\begin{array}{c}0.015^{\text {*** }} \\
(5.07)\end{array}$ & $\begin{array}{l}0.001 \\
(0.56)\end{array}$ & $\begin{array}{c}0.084^{* * *} \\
(5.35)\end{array}$ & $\begin{array}{c}0.018^{* * *} \\
(4.39)\end{array}$ & $\begin{array}{c}0.015^{* *} \\
(3.37)\end{array}$ & $\begin{array}{c}0.003^{* * *} \\
(4.54)\end{array}$ \\
\hline Wave 1 sample & $\begin{array}{c}0.008^{* * *} \\
(8.54)\end{array}$ & $\begin{array}{c}0.008^{* * *} \\
(7.81)\end{array}$ & $\begin{array}{l}0.001^{*} \\
(2.19)\end{array}$ & $\begin{array}{l}0.048^{* * *} \\
(7.66)\end{array}$ & $\begin{array}{c}0.010^{* * *} \\
(6.09)\end{array}$ & $\begin{array}{c}0.010^{* * *} \\
(5.74)\end{array}$ & $\begin{array}{c}0.002^{* * *} \\
(9.54)\end{array}$ \\
\hline Wave 2 sample & $\begin{array}{c}0.006^{* * *} \\
(4.40)\end{array}$ & $\begin{array}{c}0.006^{\text {*** }} \\
(4.19)\end{array}$ & $\begin{array}{l}0.001 \\
(1.67)\end{array}$ & $\begin{array}{c}0.035^{* *} \\
(5.99)\end{array}$ & $\begin{array}{c}0.007^{* * *} \\
(4.58)\end{array}$ & $\begin{array}{c}0.009^{* * *} \\
(5.86)\end{array}$ & $\begin{array}{c}0.001^{\text {*** }} \\
(7.33)\end{array}$ \\
\hline Full sample (height from Wave 1) & $\begin{array}{c}0.008^{* * *} \\
(8.50)\end{array}$ & $\begin{array}{c}0.008^{* * *} \\
(7.72)\end{array}$ & $\begin{array}{l}0.001 \\
(1.82)\end{array}$ & $\begin{array}{c}0.040^{* * *} \\
(7.15)\end{array}$ & $\begin{array}{c}0.008^{* *} \\
(5.87)\end{array}$ & $\begin{array}{c}0.010^{* * *} \\
(6.04)\end{array}$ & $\begin{array}{l}0.002^{* *} \\
(9.60)\end{array}$ \\
\hline Full sample (height from Wave 2) & $\begin{array}{c}0.006^{* * *} \\
(4.18)\end{array}$ & $\begin{array}{c}0.005^{* * *} \\
(3.95)\end{array}$ & $\begin{array}{l}0.001 \\
(1.89)\end{array}$ & $\begin{array}{c}0.045^{* * *} \\
(4.79)\end{array}$ & $\begin{array}{l}0.008^{* * *} \\
(3.72)\end{array}$ & $\begin{array}{c}0.011^{* *} \\
(4.38)\end{array}$ & $\begin{array}{l}0.002^{* * *} \\
(5.73)\end{array}$ \\
\hline $\begin{array}{l}\text { Standardized cognitive function } \\
\text { only }\end{array}$ & $\begin{array}{l}0.007^{* *} \\
(9.50)\end{array}$ & $\begin{array}{l}0.006^{* * *} \\
(8.77)\end{array}$ & $\begin{array}{l}0.002^{* * *} \\
(2.60)\end{array}$ & $\begin{array}{l}0.005^{* * *} \\
(8.60)\end{array}$ & $\begin{array}{l}0.004^{* * *} \\
(6.93)\end{array}$ & $\begin{array}{l}0.005^{* * *} \\
(7.40)\end{array}$ & $\begin{array}{l}0.007^{* * *} \\
(10.96)\end{array}$ \\
\hline $\begin{array}{l}\text { Standardized cognitive function } \\
\text { and height }\end{array}$ & $\begin{array}{c}0.059^{* * *} \\
(9.50)\end{array}$ & $\begin{array}{l}0.053^{* * *} \\
(8.77)\end{array}$ & $\begin{array}{l}0.017^{* * *} \\
(2.60)\end{array}$ & $\begin{array}{l}0.049^{* * *} \\
(8.60)\end{array}$ & $\begin{array}{l}0.040^{* * *} \\
(6.93)\end{array}$ & $\begin{array}{l}0.044^{* *} \\
(7.40)\end{array}$ & $\begin{array}{l}0.067^{* *} \\
(10.96)\end{array}$ \\
\hline
\end{tabular}

Notes: Each row replicates Table 4 for the corresponding sample and robustness analysis. $t$-statistics are reported in parentheses together with the coefficients which are estimated using OLS. Height is in $\mathrm{cm}$. Standard errors are clustered at the individual level where appropriate. SHARE waves 1-3 are used covering the years 2002-2008 for 13 European countries. Wave dummies and country dummies are included in all regressions.

Table A.3: IV-LATE Robustness Analysis for Greece

\begin{tabular}{|c|c|c|c|c|c|c|c|}
\hline & $\begin{array}{c}\text { Reading } \\
\text { skill }\end{array}$ & $\begin{array}{c}\text { Writing } \\
\text { skill }\end{array}$ & $\begin{array}{c}\text { Date } \\
\text { questions } \\
\text { score } \\
\end{array}$ & $\begin{array}{l}\text { Verbal } \\
\text { fluency }\end{array}$ & $\begin{array}{l}\text { Immediate } \\
\text { recall } \\
\text { score } \\
\end{array}$ & $\begin{array}{c}\text { Delayed } \\
\text { recall } \\
\text { score } \\
\end{array}$ & $\begin{array}{l}\text { Numeracy } \\
\text { test score }\end{array}$ \\
\hline $\begin{array}{l}\text { Covariates Set D: } \\
\text { Height [IV = (born 1939-1947) } \\
\times(\text { born in Greece)] } \\
\text { F-statistic in first stage }\end{array}$ & $\begin{array}{l}0.120^{* *} \\
(3.02) \\
22.34\end{array}$ & $\begin{array}{l}0.134^{* *} \\
(3.16) \\
22.39\end{array}$ & $\begin{array}{c}-0.009 \\
(-1.13) \\
24.32\end{array}$ & $\begin{array}{l}0.149 \\
(0.93) \\
24.32\end{array}$ & $\begin{array}{l}0.145^{* *} \\
(3.04) \\
24.53\end{array}$ & $\begin{array}{l}0.067 \\
(1.33) \\
24.55\end{array}$ & $\begin{array}{l}0.017^{*} \\
(2.51) \\
24.81\end{array}$ \\
\hline $\begin{array}{l}\text { Covariates Set E: } \\
\text { Height }[\text { IV = (born 1939-1947) } \\
\times(\text { born in Greece)] } \\
\text { F-statistic in first stage }\end{array}$ & $\begin{array}{l}0.115^{* *} \\
(2.90) \\
21.73\end{array}$ & $\begin{array}{l}0.127^{* *} \\
(3.02) \\
21.77\end{array}$ & $\begin{array}{c}-0.009 \\
(-1.08) \\
23.46\end{array}$ & $\begin{array}{l}0.109 \\
(0.66) \\
23.50\end{array}$ & $\begin{array}{l}0.140^{* *} \\
(2.90) \\
23.67\end{array}$ & $\begin{array}{l}0.061 \\
(1.19) \\
23.69\end{array}$ & $\begin{array}{l}0.016^{*} \\
(2.38) \\
24.00\end{array}$ \\
\hline $\begin{array}{l}\text { Covariates Set F: } \\
\text { Height [IV = (born 1939-1947) } \\
\times(\text { born in Greece)] } \\
\text { F-statistic in first stage }\end{array}$ & $\begin{array}{l}0.096^{*} \\
(2.51) \\
19.71\end{array}$ & $\begin{array}{l}0.106^{* *} \\
(2.62) \\
19.72\end{array}$ & $\begin{array}{c}-0.011 \\
(-1.21) \\
21.50\end{array}$ & $\begin{array}{c}0.031 \\
(0.18) \\
21.54\end{array}$ & $\begin{array}{l}0.123^{*} \\
(2.55) \\
21.62\end{array}$ & $\begin{array}{l}0.037 \\
(0.72) \\
21.64\end{array}$ & $\begin{array}{l}0.014^{*} \\
(2.00) \\
21.93\end{array}$ \\
\hline Observations & 6405 & 6406 & 9694 & 9676 & 9690 & 9691 & 9666 \\
\hline
\end{tabular}

Notes: Only the coefficients on height for the OLS and IV regression are reported in the above table for people born between 1939 and 1955. $t$-statistics are reported in parentheses. Non-war countries: Spain, Switzerland, Sweden. Covariates Set D: age, age ${ }^{2}$, male. Covariates set E: Covariates Set D + father's occupational prestige at age 10 , childhood health. Covariates set F: Covariates Set D + Covariates Set E + years of education. Country dummies and wave dummies are included in all regressions. 